\title{
Origin of dolomites in the Boat Harbour Formation, St. George Group, in western Newfoundland, Canada: implications for porosity development
}

\author{
K. AZMY \\ Department of Earth Sciences \\ Memorial University of Newfoundland \\ St. John's, NL A1B $3 X 5$ \\ kazmy@mun.ca \\ D. LAVOIE \\ Geological Survey of Canada \\ GSC-Q, Natural Resources Canada \\ 490 de la Couronne \\ Québec City, QC G1K $9 A 9$
}

\author{
I. KNIGHT \\ Geological Survey of Newfoundland and Labrador \\ Department of Natural Resources \\ Government of Newfoundland and Labrador \\ P.O. Box 8700 \\ St. John's, NL A1B 4J6
}

\author{
G. $\mathrm{CHI}$ \\ Department of Geology \\ University of Regina \\ Regina, SK S4S 0A2
}

\begin{abstract}
The lower part of the St. George Group of western Newfoundland consists of Tremadocian shallow marine platform carbonates of the Boat Harbour (about $180 \mathrm{~m}$ thick) and the underlying Watts Bight (about $60 \mathrm{~m}$ thick) formations. In the Boat Harbour Formation, dolomitization is pervasive at the top of most shallowing-upward, metre-scale, peritidal hemicycles. Petrographic examination of the Boat Harbour Formation carbonates suggests that the succession has been affected by at least three phases of dolomitization, which influenced the final rock porosity. These phases have crystal-size ranges of about 4 to $40 \mu \mathrm{m}$ (earliest dolomite D1), 50 to $150 \mu \mathrm{m}$ (D2), and $300 \mu \mathrm{m}$ to $20 \mathrm{~mm}$ (saddle dolomite D3), respectively. They occur as both replacements and cements and exhibit dull (D1 and D3) to zoned (D2) luminescence under the cold cathodoluminoscope. The occurrence of near-micritic size dolomites (about 4-40 $\mu \mathrm{m}$ ) may suggest that dolomitization started at low temperatures during early stages of diagenesis. The lack of evaporite interbeds in the formation and the depleted $\delta^{18} \mathrm{O}$ values $(-6.2 \pm 0.8 \%$ VPDB) as well as the low $\mathrm{Sr}$ contents $(168 \pm 45 \mathrm{ppm})$ of the earliest dolomites likely exclude a brine origin from evaporated seawater. The $\mathrm{Sr} / \mathrm{Ca}$ molar ratios (0.0069 to 0.0017$)$, calculated for the earliest dolomitizing fluid, suggest a mixture of marine and meteoric waters possibly in a mixing zone environment. The petrographic features and geochemical attributes of D2 and D3 phases, such as their depleted $\delta^{18} \mathrm{O}$ values $(-6.9 \pm 1.5 \%$ and $-8.3 \pm 0.9 \%$ VPDB, respectively) and $\mathrm{Sr}$ contents (177 \pm 76 and $117 \pm 33 \mathrm{ppm}$, respectively), suggest that they were formed under relatively deeper burial conditions and possibly from hydrothermal fluids which is supported by homogenization temperatures (up to $135^{\circ} \mathrm{C}$ ) and estimates of salinities (up to $23 \mathrm{wt} . \% \mathrm{NaCl}$ ) in the latest dolomites (D3). Based on visual estimates from thin sections, the porosity varies from $<1 \%$ in most of the formation to about $10 \%$ in a dolomitized algal lime mudstone bed in the upper part of the formation, a few metres below the Boat Harbour Disconformity. Except for some vugs, the majority of pores are intercrystalline and associated with D2.

The dolomitization events recorded by the Boat Harbour Formation carbonates resemble, in their succession and geochemical signatures, those previously documented in the Aguathuna Formation. However, significant differences are noted with the dolomitization events recorded in the Lower Ordovician Romaine Formation on Anticosti Island; these differences are tentatively associated with the very distinct tectonic settings of each case.
\end{abstract}

\section{RÉSUMÉ}

La partie inférieure du Groupe de St.George de l'ouest de Terre-Neuve est formée de carbonates néritiques d'eau peu profonde du Trémadocien de la Formation de Boat Harbour (d'environ $180 \mathrm{~m}$ d'épaisseur) et de la Formation de Watts Bight sous-jacente (d'environ $60 \mathrm{~m}$ d'épaisseur). Dans la Formation de Boat Harbour, la dolomitisation est envahissante au sommet de la plupart des demi-cercles péritidaux de moindre profondeur vers le haut, à l'échelle métrique. L'analyse pétrographique des carbonates de la Formation de Boat Harbour suggère qu'au moins trois épisodes de dolomitisation ont agit sur la 
succession, ce qui a influé sur la porosité finale de la roche. La taille des cristaux de ces épisodes de dolomitisation varie de $4 \mu \mathrm{m}$ à $40 \mu \mathrm{m}$ (dolomite précoce D1), de $50 \mu \mathrm{m}$ à $150 \mu \mathrm{m}$ (D2) et de $300 \mu \mathrm{m}$ à $20 \mathrm{~mm}$ (dolomite en selle D3), respectivement. Ces épisodes ont entrainé le remplacement de substance et la cimentation d'espaces intergranulaires et les dolomites révèlent une luminescence variant de terne (D1 et D3) à zonée (D2) sous le cathodoluminoscope à froid. La présence de dolomite de dimension quasi-micritique (de $4 \mu \mathrm{m}$ à $40 \mu \mathrm{m}$ environ) peut signifier que la dolomitisation avait débuté à basse température durant les stades précoces de la diagenèse. Le manque d'évaporites interstratifiées dans la formation et les valeurs appauvries en $\mathrm{d}^{18} \mathrm{O}(? 6,2 \pm 0,8 \%$ VPDB$)$, ainsi que le faible contenu en $\mathrm{Sr}(168 \pm 45 \mathrm{ppm})$ dans les dolomites les plus précoces excluent, selon toute probabilité, une origine saumâtre provenant d'eau marine évaporée. Les ratios molaires de $\mathrm{Sr} / \mathrm{Ca}$ (de 0,0069 à 0,0017 ) calculées pour les fluides de dolomitisation les plus précoces suggèrent un mélange d'eaux marine et météorique, vraisemblablement dans une zone de mélange. Les caractéristiques pétrographiques et les attributs géochimiques des épisodes $\mathrm{D} 2$ et $\mathrm{D} 3$, en l'occurrence leurs valeurs appauvries en $\mathrm{d}^{18} \mathrm{O}$ (?6,9 $\pm 1,5 \%$ et $-8,3 \pm 0,9 \%$ VPDB, respectivement) et en $\operatorname{Sr}(177 \pm 76$ et $117 \pm 33 \mathrm{ppm}$, respectivement) suggèrent qu'elles se soient formées dans des conditions d'enfouissement relativement profondes et soient vraisemblablement issues de fluides hydrothermaux, ce que corrobore des températures d'homogénéisation (jusqu'à $135^{\circ} \mathrm{C}$ ) et des salinités estimatives (jusqu'à $23 \%$ d'équivalent en poids $\mathrm{NaCl}$ ) dans les dolomites les plus tardives (D3). Selon les estimations visuelles de lames minces, la porosité varie de moins de $1 \%$ pour la plus grande partie de la formation, à environ $10 \%$ pour un lit de mudstone calcaire algacé dolomitisé, dans la partie supérieure de la formation, à quelques mètres au-dessous de la discordance de Boat Harbour. À l'exception de vacuoles, la majorité des pores sont intergranulaires et associées à D2.

Sur le plan de leurs successions et de leurs signatures géochimiques, les épisodes de dolomitisation enregistrés dans les carbonates de la Formation de Boat Harbour ressemblent à ceux qui ont été documentés antérieurement dans la Formation d'Aguathuna. Cependant, on remarque des différences notables par rapport aux épisodes de dolomitisation enregistrés dans la Formation de Romaine de l'Ordovicien inférieur sur l'île d'Anticosti; ces différences sont pour l'instant associées à des contextes tectoniques très distincts dans chaque cas.

Michel Ory

\section{INTRODUCTION}

Dolomitization in the Paleozoic carbonate reservoirs of North America has become the focus of studies due to the occurrence of major hydrocarbon accumulations in the dolomitized horizons (cf. Haywick, 1984; Lane, 1990; Cooper et al., 2001; Langdon and Mireault, 2004; Lavoie et al., 2005, Azmy et al., 2008). Porosity enhancement, related to diagenetic events, is associated with hydrothermal dolomites in carbonate reservoirs of the Appalachians and the adjacent St. Lawrence Platform domain such as those found in the Lower Ordovician Romaine Formation of the Anticosti Basin (Lavoie et al., 2005), the Lower Silurian La Vieille and Sayabec formations in Gaspé and northern New Brunswick (Lavoie and Morin, 2004; Lavoie and Chi, 2006), and the Upper Ordovician Trenton-Black River dolomites in New York and Anticosti (Smith, 2006; Lavoie and Chi, in press).

Field studies of middle to late Tremadocian rocks of the St. George Group in western Newfoundland indicate that there are two disconformities in the peritidal cyclic carbonates of the Boat Harbour Formation (the unnamed lower disconformity and the upper Boat Harbour Disconformity) and that there is extensive dolomitization below both disconformities, which have evidences of associated karstification (Knight et al., 2008). It seems that early karstification possibly played a role in the distribution and enhancement of dolomitization and the exposure to meteoric diagenesis likely developed an early diagenetic pore system that contributed to dolomitization.

In western Newfoundland, the association of dolomitized facies of the St. George Group with organic rich shale (Green
Point Formation of the Cow Head Group) and overlying impermeable layers (limestone in the Table Point Formation of the Table Head Group) is critical to the presence of an efficient hydrocarbon system. Moreover, the Middle Devonian Acadian Orogeny resulted in the development of structural traps (Baker and Knight, 1993; Fowler et al., 1995; Stockmal et al., 1998; Cooper et al., 2001: Knight et al., 2008). Port au Port \#1 discovery well on the Port au Port Peninsula (Fig. 1) produced about $3400 \mathrm{~m}^{3}$ of oil between 1995 and 2001 (cf. Langdon and Mireault, 2004) from the Aguathuna Formation (Azmy et al., 2008), uppermost unit of the St. George Group, and recent testing of a sidetrack hole has resulted in a stabilized flow of $49.6 \mathrm{~m}^{3} /$ day (312 barrels).

The main objectives of the current investigation are to: 1) study the petrography of the Boat Harbour Formation dolomites; 2) identify the origin and nature of the dolomitizing fluids in order to understand the diagenetic controls on porosity development; and 3) compare the dolomitization process with that of adjacent Lower Ordovician units.

\section{Geologic Setting and Stratigraphy}

The Boat Harbour Formation occurs in the western Newfoundland Appalachians (Fig. 1) within a thick marine platform succession that has been intensively affected by complex Paleozoic orogenic events (cf. Cooper et al., 2001; van Staal, 2005; Lavoie, 2008). The formation was deposited as part of a broad low-energy platform that dominated the St. Lawrence Promontory during the early Ordovician. The 
formation is dominated by numerous, metre-scale, shallowing upward peritidal parasequences that, for the most part, form the upper part of a long term, 3rd order Tremadocian megacycle (Knight and James, 1987; Knight et al., 2008).

The lithostratigraphy and cyclic peritidalites of the St. George Group has been described and refined by several authors (e.g. Pratt and James, 1986; Knight and James, 1987; Knight, 1991; Cooper et al., 2001; Knight et al., 2007, 2008) and is summarized below. The group consists of Lower Ordovician (Tremadoc-Arenig) platform carbonates which, from bottom to top, include the Watts Bight, Boat Harbour, Catoche, and Aguathuna formations (Fig. 2).

The Boat Harbour Formation is well exposed at Isthmus Bay near Stephenville (Fig. 1), where it is divided into three members (Fig. 2) separated by two disconformities (Knight et al., 2008), an unnamed lower disconformity (Figs. 2 and 3a) and the stratigraphically higher Boat Harbour Disconformity (Fig. 2 and 3b). Both disconformities are associated with paleokarst and distinctive diagenesis such as pervasive dolomitization, and are marked by micro and macro faunal changes
(Knight and James, 1987; Knight, 1991; Ji and barnes, 1994; Boyce and Stouge, 1997; Knight et al., 2007, 2008). Each member is dominated by peritidal parasequences but each member is subtly different from its neighbor. The lower and middle members (unnamed) are part of the Tremadocian megacycle of Knight and James (1987) and are essentially offlapping, high-stand deposits. The upper member (Fig. 2), the Barbace Cove Member (Knight and James, 1987; Knight, 1991) is the initial part of a later Arenig/Floian transgressive system tract that, with global eustatic sea level rise, onlapped the upper disconformity onto and across the Laurentian margin (upper megacycle of Knight and James, 1987).

The lower member (about $44 \mathrm{~m}$ thick) consists of metrescale, upward-shallowing, peritidal cycles of rudstone and/or pebbly grainstone, burrowed wackestone and thinly bedded dolomitic limestone. The cycles are capped by dololaminites that underwent desiccation. The upper part of the member is extensively dolomitized and its upper boundary (lower disconformity surface) is marked by thin bedding parallel breccia bodies, geopetal-filled cavities and fenestral development.

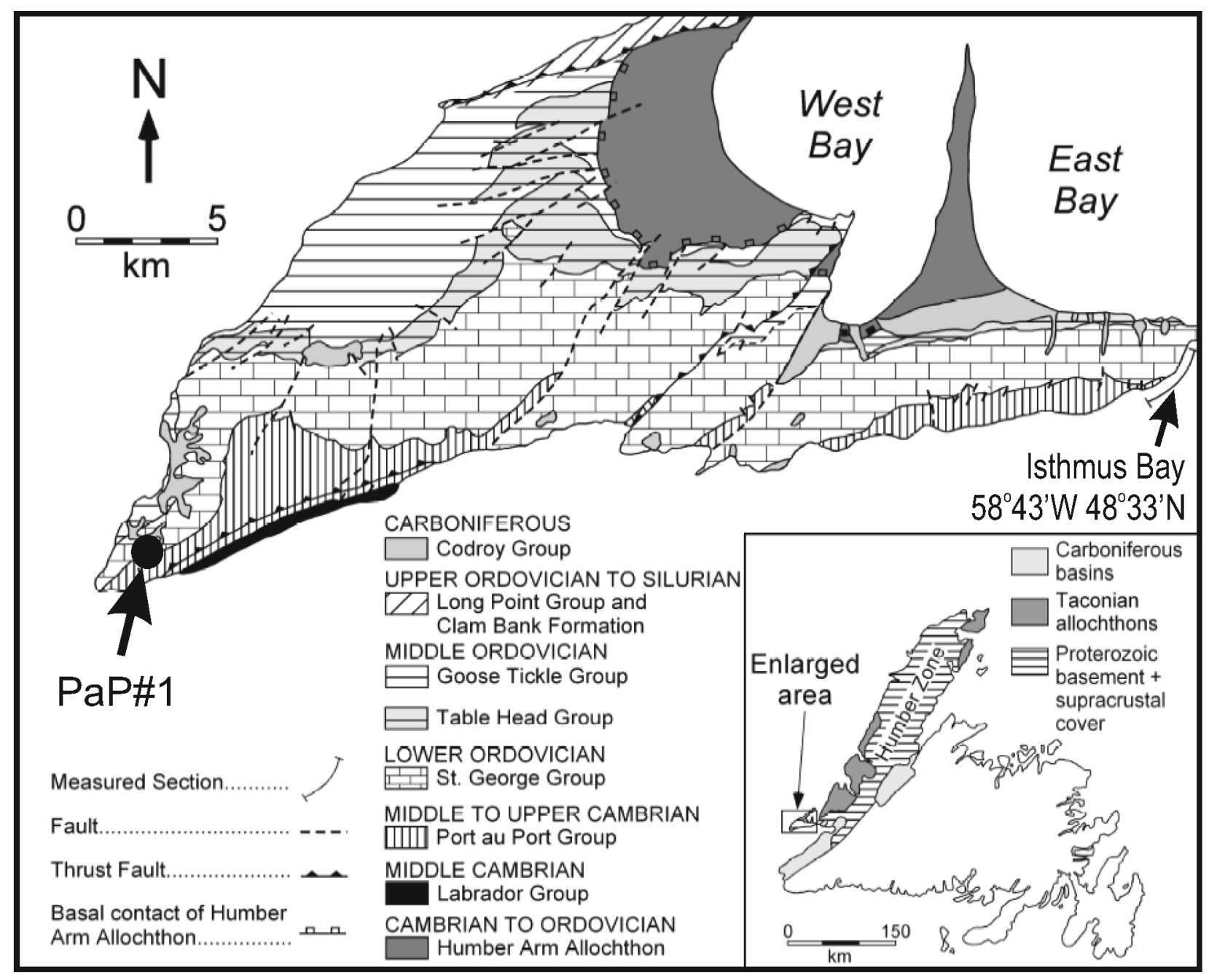

Fig. 1. A map of the study area showing the location of a well-exposed outcrop of the Boat Harbour Formation along the Isthmus Bay, Port au Port Peninsula, in western Newfoundland (modified from Knight et al., 2008). PaP\#1 is the approximate location of the Port au Port discovery \#1 well (see text for detail). 

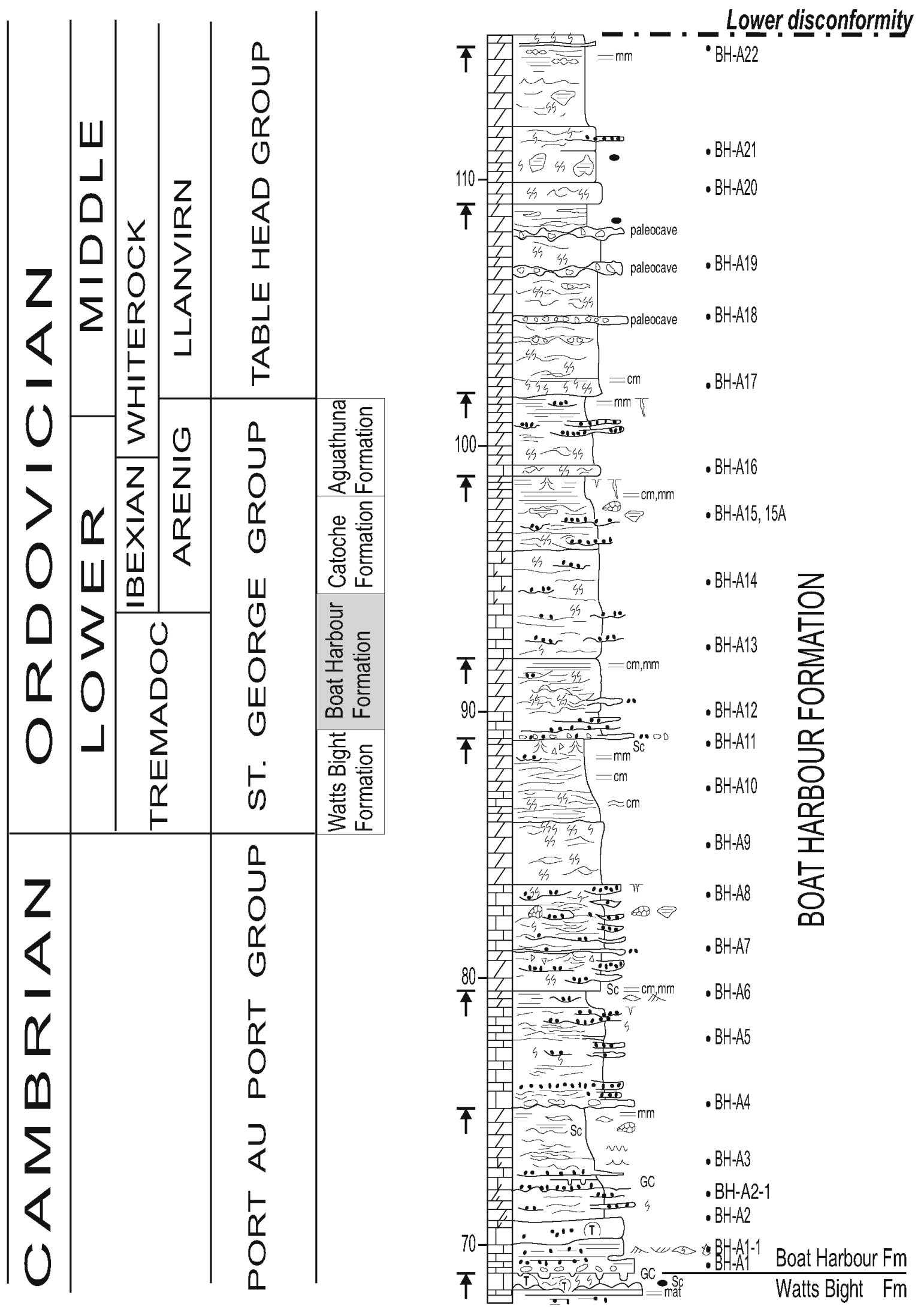

Fig. 2. Detailed lithostratigraphic log of the Boat Harbour Formation showing the location of samples analyzed in the current study (after Knight et al., 2008). 


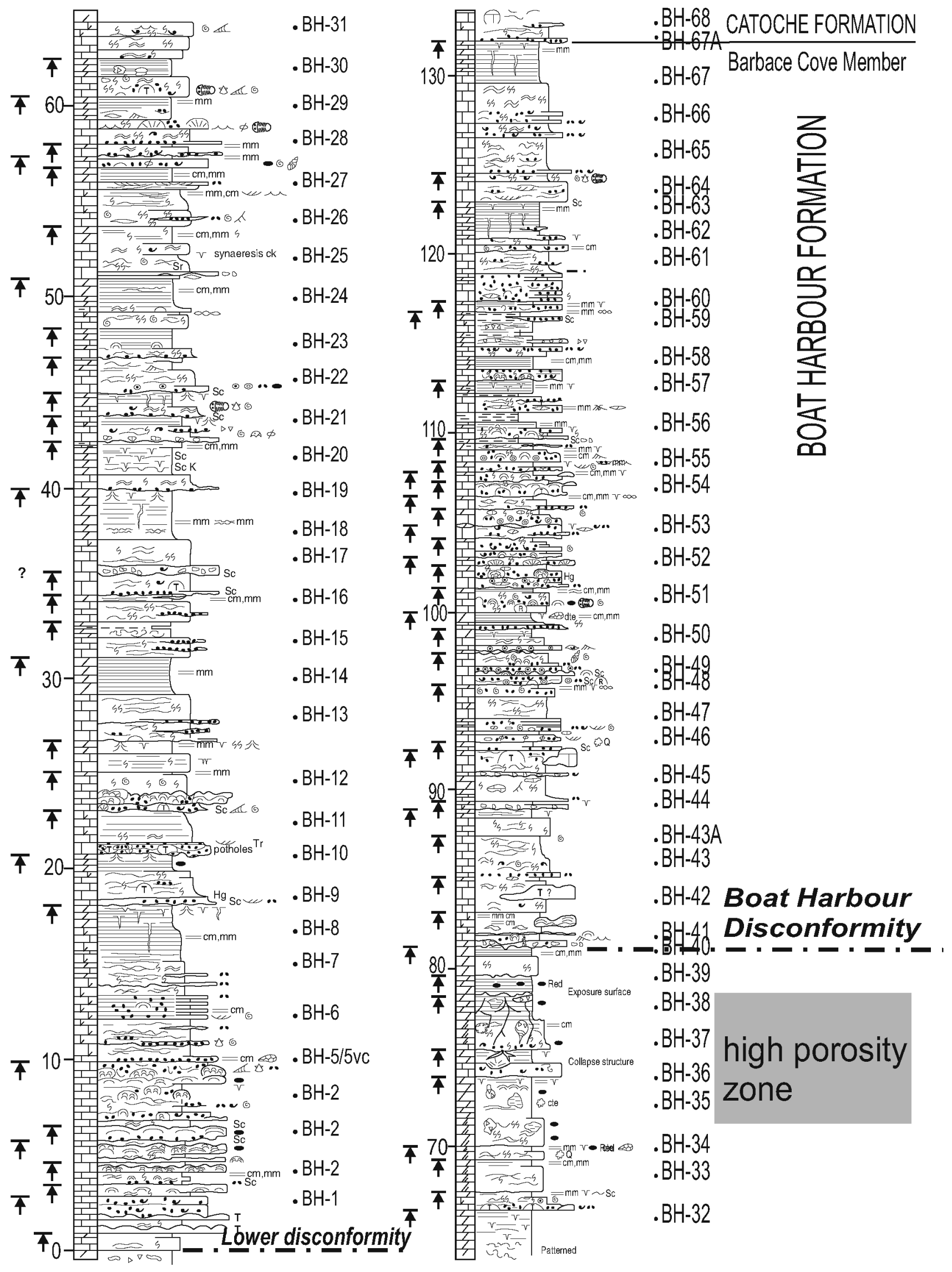

Fig. 2. (Continued.) 


\section{SYMBOLS}

\begin{tabular}{|c|c|}
\hline$u$ & Arenicolites / Diplocrateria \\
\hline W & Skolithus \\
\hline$\alpha$ & Chondrites \\
\hline 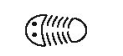 & Trilobite \\
\hline 禺 & Opercula \\
\hline$\pi$ & Cephalopod \\
\hline$\odot$ & Gastropod \\
\hline$\Leftrightarrow$ & High-spired gastropod \\
\hline$\infty$ & Brachiopod \\
\hline 萧 & Pulchrilamina / Lichenaria \\
\hline 0 & Sponge \\
\hline$\curvearrowright$ & Mound \\
\hline $\mathrm{T}$ & Thrombolite (R-Renalcis) \\
\hline$\curvearrowright$ & Stromatolite \\
\hline बाम & Digitate \\
\hline$\infty 0$ & Pebbles \\
\hline$\bullet$ & Skeletal grain \\
\hline$\cdots$ & Intraclast \\
\hline$\phi$ & Peloid \\
\hline () & Oncolite \\
\hline$\odot$ & Oolite \\
\hline
\end{tabular}

\begin{tabular}{|c|c|}
\hline$\cdots$ & Grainstone lense \\
\hline we & Trough cross bedding \\
\hline$\ldots$ & Planar cross bedding \\
\hline$\approx$ & Uneven stylo-thin stratification \\
\hline$=\mathrm{mm} \mathrm{cm}$ & Planar lamination, thin bedding \\
\hline$=\mathrm{mm} \mathrm{cm}$ & Undulose lamination, thin bedding \\
\hline$\Phi$ & Limestone nodule \\
\hline - & Chert \\
\hline- & Chert outlining mounds \\
\hline$\checkmark$ & Mudcrack \\
\hline 3 & Fissure crack \\
\hline$\infty$ & Fenestra \\
\hline 公 & Tepee \\
\hline hr & Ripple mark \\
\hline$\infty$ & Flaser \\
\hline$\infty$ & Dolostone lens \\
\hline sos & Nodular/parted \\
\hline 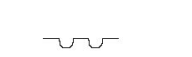 & Gutter cast \\
\hline run & Hardground \\
\hline 2 & Convoluted \\
\hline$>\nabla$ & Breccia \\
\hline$\infty x$ & Vug \\
\hline$\sqrt{3}$ & $\begin{array}{l}\text { Cauliflower nodule (cte-calcite, } \\
\text { dte-dolomite, Q-quartz) }\end{array}$ \\
\hline$\Leftrightarrow$ & Geopetal cavity \\
\hline
\end{tabular}

\section{LITHOLOGY}
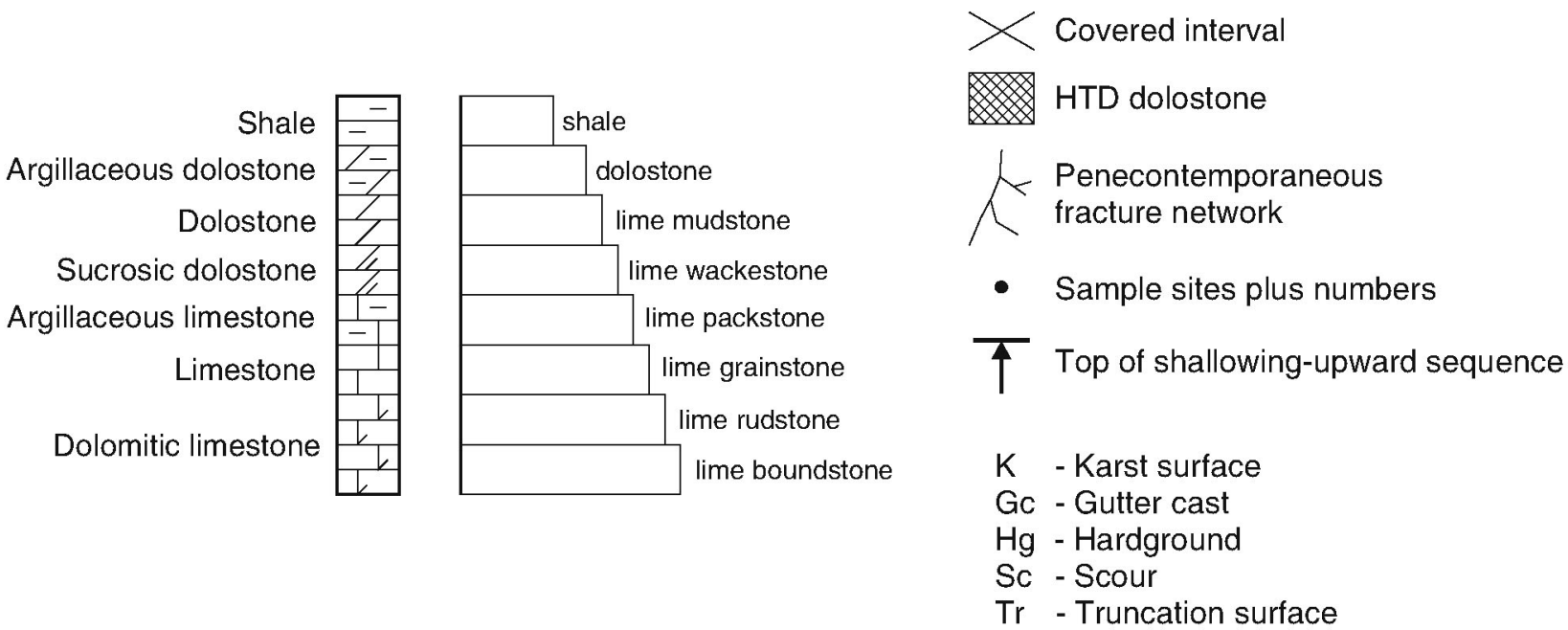

Fig. 2. (Continued.) 
The middle member (about $83 \mathrm{~m}$ thick) is bounded by the lower disconformity at the base and by the Boat Harbour Disconformity at its top (Figs. 2 and $3 \mathrm{~b}$ ). It is composed of shallowing-upward cycles that are similar (facies and architecture ) to the lower member but include many horizons of stromatolitic, thrombolitic and microbial boundstone mounds including a basal marker that has been mapped regionally and widely beyond the Port au Port Peninsula. Truncation surfaces and intercycle karsts are also locally developed.

Paleokarst occurs at and below the Boat Harbour Disconformity. Paleo-cavities infilled by dolostone breccia, geopetal laminated dolostone and green shale, occur down to 10 $\mathrm{m}$ below the disconformity. The upper 15 to $20 \mathrm{~m}$ of the member is extensively dolomitized and silicified, overprinting multiple karst events at the top of at least three shallowing-upward cycles below the disconformity (Knight et al., 2007; 2008). Fenestrae and vugs are occluded with coarse $\mathrm{cm}$-scale milkywhite dolomites and calcite cements within this upper interval.

The upper member (Barbace Cove Member, about $52 \mathrm{~m}$ thick) is marked at its base by the Boat Harbour Disconformity and at its top by the conformable Boat Harbour/Catoche boundary. It consists of a succession of cyclic peritidal carbonates rich in skeletal and intraclastic grainstone associated with common thrombolitic and stromatolitic boundstone mounds with burrowed dolomitic limestone and caps of laminated dolostone. In the top few cycles, there are thick caps of laminated dolomitic limestones. Two thin beds of green-grey shale occur in laminites midway through the member on Isthmus Bay. The member hosts a robust and diverse fossil community of Arenig/Floian age (Boyce, 1997; Ji and Barnes, 1994; Boyce and Stouge, 1997; Knight et al., 2007, 2008).

The lithofacies of the Boat Harbour Formation carbonates indicate warm marine conditions (Knight et al., 2008), consistent with the low latitudinal setting of the margin of Laurentia at that time (James et al., 1989). Dolomitization is extensive throughout the upper member and porosity is common below the Boat Harbour Disconformity surface. However, field studies show no lateral variations in dolomitization across the sampled outcrop. Paleo-cavities (karsts), infilled by dolostone breccia and geopetal laminated dolostone occur in places down to $10 \mathrm{~m}$ below the disconformity.

\section{Methodology}

Samples were collected at high resolution (sampling interval of about $2 \mathrm{~m}$, Appendix 1) from a complete section (about $180 \mathrm{~m}$, Fig. 2) of the Boat Harbour Formation along the western shore of Isthmus Bay (longitude $58^{\circ} 43^{\prime} \mathrm{W}$, latitude $48^{\circ} 33^{\prime} \mathrm{N}$ ) near Stephenville (Fig. 1) in western Newfoundland (Knight et al., 2008). Thin sections of the samples were examined under standard polarizing microscope and cathodoluminoscope (CL) and stained with Alizarin Red-S and potassium ferricyanide solutions (Dickson, 1966). A polished mirror-image slab of each thin section was also prepared for microsampling and washed with deionized water. Cathodoluminescence was performed using a ELM-3R cold cathode instrument operated at about
$12 \mathrm{kV}$ accelerating voltage and about $0.7 \mathrm{~mA}$ gun current intensity. Fluid inclusion microthermometry was conducted on double polished thick sections, using a calibrated Linkam THMSG 600 stage at the Geofluids Laboratory of the University of Regina. The precision is $\pm 0.2^{\circ} \mathrm{C}$ for melting temperatures and $\pm 1^{\circ} \mathrm{C}$ for homogenization temperatures measurements. Salinities were calculated from the final ice-melting temperatures using a program by Chi and $\mathrm{Ni}$ (2007) for the system of $\mathrm{H}_{2} \mathrm{O}-\mathrm{NaCl}-\mathrm{CaCl}_{2}$.

Approximately $4 \mathrm{mg}$ were microsampled from the cleaned slabs with a low-speed microdrill. For C- and O-isotope analyses, about $200 \mu \mathrm{g}$ of powder sample was reacted in inert atmosphere with ultrapure concentrated $(100 \%)$ orthophosphoric acid at $70^{\circ} \mathrm{C}$ in a Thermo-Finnigan Gasbench II. The $\mathrm{CO}_{2}$ produced from the reaction was automatically flushed through a chromatographic column and delivered to the source of a ThermoFinnigan DELTA V plus isotope ratio mass spectrometre in a stream of helium, where the gas was ionized and measured for isotope ratios. Uncertainties of better than $0.1 \%$ $(2 \sigma)$ for the analyses were determined by repeated measurements of NBS-19 $\left(\delta^{18} \mathrm{O}=-2.20 \%\right.$ and $\delta^{13} \mathrm{C}=+1.95 \%$ vs. VPDB $)$ and L-SVECS $\left(\delta^{18} \mathrm{O}=-26.64 \%\right.$ and $\delta^{13} \mathrm{C}=-46.48 \%$ vs. VPDB $)$ as well as internal standards during each run of samples.

For elemental analyses, a subset of sample powder was digested in 2.5\% (v/v) pure $\mathrm{HNO}_{3}$ acid for 70-80 min. and analyzed for $\mathrm{Ca}, \mathrm{Mg}, \mathrm{Sr}, \mathrm{Mn}$ and $\mathrm{Fe}$ (Coleman et al., 1989) using a HP 4500plus ICPMS at Memorial University of Newfoundland. The relative uncertainties of these measurements are better than $5 \%$. Calculations of major and trace element concentrations are based on an insoluble residue-free basis ( $100 \%$ soluble dolomite or calcite).

A subset of samples representing different dolomite generations was selected for Sr-isotope analysis. About $2 \mathrm{mg}$ of the powdered sample was dissolved in $2.5 \mathrm{~N}$ ultrapure $\mathrm{HCl}$ and after evaporation $\mathrm{Sr}$ was extracted with quartz glass exchange columns filled with Bio Rad AG50WX8 ion exchange resin. Finally, about $100 \mu \mathrm{g}$ Sr was loaded on Re filaments using a $\mathrm{Ta}_{2} \mathrm{O}_{5}-\mathrm{HNO}_{3}-\mathrm{HF}-\mathrm{H}_{3} \mathrm{PO}_{4}$ solution. Measurements were performed with a Finnigan MAT 262 multicollector mass spectrometer at the Institut für Geologie, Mineralogie und Geophysik, Ruhr Universität, Bochum, Germany (cf. Azmy et al., 1999, 2001).

Two standard reference materials were utilized as quality control of Sr isotope ratio measurements, NIST (NBS) 987 and USGS EN-1. The latter, representing modern sea water and treated like an ordinary sample, gave a ${ }^{87} \mathrm{Sr} /{ }^{86} \mathrm{Sr}$ value of $0.709159 \pm 0.000004$ ( $2 \sigma$ calculated from 73 measurements). About $75 \mu \mathrm{g}$ Sr of the NIST (NBS) 987 standard reference material was directly loaded onto the filament and these results therefore represent only the internal reproducibility of mass-spectrometry. Its value was $0.710238 \pm 0.000005$, based on 72 measurements. The average composite blank for $\mathrm{Sr}$, including chemicals, ion-exchange columns and loading blank, did not exceed $0.0085 \mu \mathrm{g}$. The measured ${ }^{87} \mathrm{Sr} /{ }^{86} \mathrm{Sr}$ ratio was normalized to a value of 8.375209 for the ${ }^{88} \mathrm{Sr} /{ }^{86} \mathrm{Sr}$ ratio. The ${ }^{87} \mathrm{Sr} /{ }^{86} \mathrm{Sr}$ measurements were normalized to NBS 987 values 
bracketing the samples $(0.710247)$ and corrected for deviation from value stated by McArthur (1994).

\section{Results}

\section{Petrography}

The microfacies of the Boat Harbour Formation carbonates range from skeletal grainstones to microbial fenestral lime mudstones and wackestones (Knight et al., 2008). Petrographic examination indicates that Boat Harbour Formation carbonates record three phases of sedimentary or void-filling calcites. These are, from youngest to oldest, Calcite $1(\mathrm{C} 1$, the marine calcite including the micrite and microbial mud with skeletal fragments), Calcite 2 ( $\mathrm{C} 2$, early equant cements in grainstones), and Calcite $3[\mathrm{C} 3$, and latest coarse (up to $3 \mathrm{~cm}$ ) blocky cements filling fractures and vugs] (Fig. 4). All calcite phases are dull to non-luminescent under the cold cathodoluminoscope.

Dolomitization significantly affected the Boat Harbour Formation carbonates particularly at the top of most shallowing-upward parasequences and pervasively replaced several complete cycles for $10 \mathrm{~s}$ of metres below the disconformities (Fig. 2), which may suggest that it occurred irrespective of lithological or facies controls. Based on field observations,

(a)

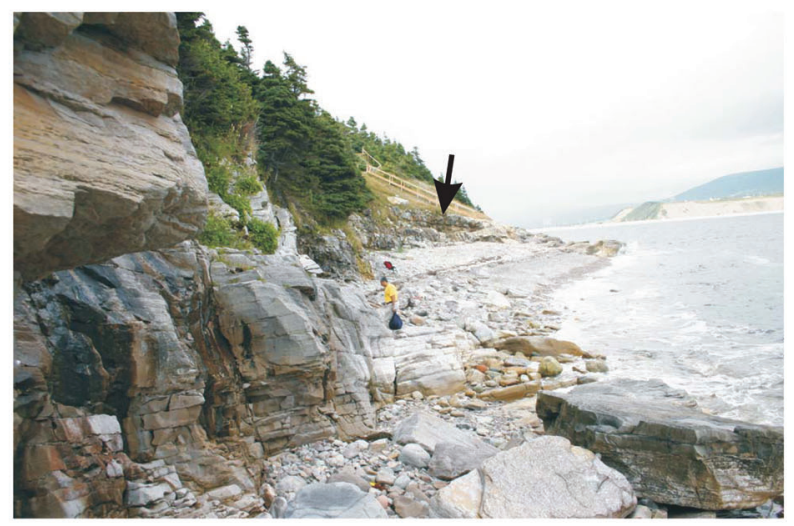

(b)

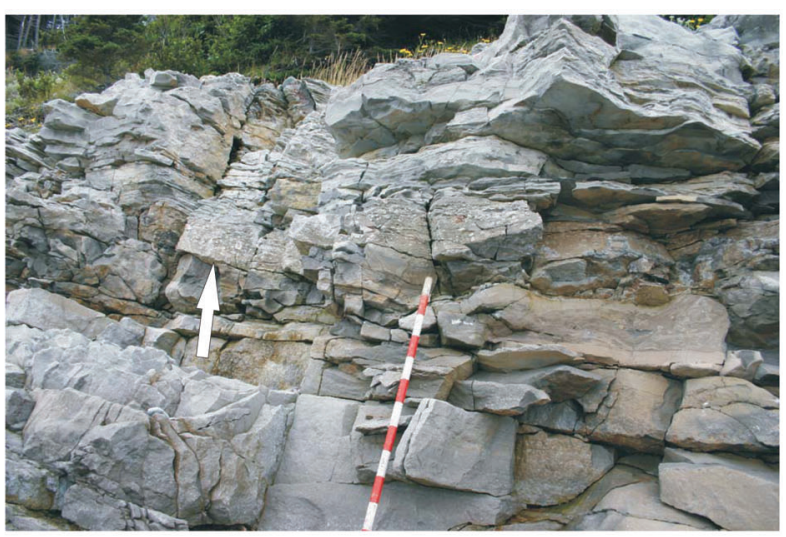

Fig. 3. Photos showing (a) the location of the lower disconformity at the top of the lower member of the Boat Harbour Formation, Isthmus Bay section (arrow) and (b) The Boat Harbour Disconformity (arrow), Isthmus Bay, overlain by a conglomerate of dolostone and thinly bedded grainy limestone. Measuring stick is $1.1 \mathrm{~m}$ thick (modified from Knight et al., 2008). petrography and cathodoluminescence (CL), three major phases of dolomitization have been identified (Figs. 4 and 5a-d). These, from the oldest to the youngest, are: Dolomite 1 (D1, pervasive dolomicrite), Dolomite 2 (D2, equant replacive dolomite) and Dolomite 3 (D3, latest large equant pore-filling to replacive saddle dolomite).

Dolomite 1 (Fig. 5a) is the most abundant type and consists of sub- to euhedral inclusion-rich pervasive dolomite in the capping dololaminites and dolostones and in the pervasive, sub-disconformity dolostones. D1 is generally mimetic (cf. Sibley, 1982; Budd, 1997) and may preserve sedimentary fabric. It has crystal sizes varying approximately from 4 to $40 \mu \mathrm{m}$ and exhibits dull luminescence (cf. Machel and Mountjoy, 1986, 1990) under CL examination.

Dolomite 2 consists of coarse, equant sub- to euhedral crystals that developed during progressive replacement or recrystallization (e.g. Lonnee and Machel, 2006; Wierzbicki et al., 2006). The crystals vary in size between about 50 and $150 \mu \mathrm{m}$ and exhibit cloudy cores with clear rims (e.g. Azmy et al., 2008) under plane polarized light (Fig. 5b) and concentric zoned luminescence under CL (Fig. 5c). D2 is cut by solution seams and microstylolites of shallow burial environment. Intercrystalline porosity $(\varnothing)$ is associated with D2 and visually estimated between 5 to $10 \%$ in the zone immediately below the Boat Harbour Disconformity (Fig. 2). This is in contrast to the $<1 \%$ porosity seen elsewhere in the Boat Harbour Formation dolostones. Dolomite 3 consists of pore- and fracture-filling to occasionally replacive coarse sub- to anhedral crystals $(>0.5 \mathrm{~mm})$ with a distinctive milky appearance in polished thin sections and slabs. Crystals usually exhibit undulose extinction and dull CL (Fig. 5d). These petrographic characteristics are generally associated with saddle dolomites regardless of the age or the type of sedimentary basins (e.g. Azmy et al., 2001; Al-Aasm, 2003; Al-Aasm and Clarke, 2004; Lavoie and Morin, 2004). D3 was followed by the precipitation of C3 (Fig. 4b).

\section{FLuid InCLusions}

Microthermometric measurements of primary fluid inclusions from D2, D3 and C3 provide melting and homogenization temperatures (Th) and estimates of salinity (cf. Goldstein and Reynolds, 1994; Chi and Ni, 2007) for each phase (Table 1 [pages 12 and 13] and Fig. 6a-b). The measured Th provides an estimate of minimum entrapment temperatures. The examined inclusions are parallel to crystal facets and the vapor bubble size (Table 1) for the two-phase (liquid-vapor) fluid inclusions is within 10 to $15 \%$ of the total inclusion size except for a few samples, which is consistent with primary origin in a deep burial setting (Goldstein and Reynolds, 1994). The Tm's (final ice-melting temperature) of each fluid inclusion assemblage are generally consistent and the estimated salinities are high and consistent with those from burial brines (Goldstein and Reynolds, 1994).

Fluid inclusions within D1 crystals (mainly dolomicrite) were too small to measure (cf. Goldstein and Reynolds, 1994). Fluid inclusions within D2 crystals yielded Th that range from 
$93^{\circ}$ to $105^{\circ} \mathrm{C}\left(101 \pm 5.7^{\circ} \mathrm{C}, n=4\right)$ and final ice-melting temperatures $\left(\mathrm{Tm}_{\text {ice }}\right)$ between $-18.6^{\circ}$ to $-9.6^{\circ} \mathrm{C}\left(-15.0 \pm 4.7^{\circ} \mathrm{C}, n=3\right)$, with salinity estimates that range from 13.6 to $21.1 \mathrm{wt} \%$ $(18.3 \pm 4.1$ wt. $\%, n=3)$. Fluid inclusions in D3 crystals have Th ranging from $100^{\circ}$ to $135^{\circ} \mathrm{C}\left(120.1 \pm 14.6^{\circ} \mathrm{C}, n=14\right)$, final icemelting temperatures from $-21.7^{\circ}$ to $-1.0^{\circ} \mathrm{C}\left(-11.8 \pm 5.8^{\circ} \mathrm{C}\right.$, $n=15)$, and salinities from 1.7 to 23.4 wt. $\%$ (15.0 \pm 5.9 wt. $\%$, $n=15)$. Measurable 2-phase fluid inclusions are relatively abundant in $\mathrm{C} 3$, giving Th ranging between $68^{\circ}$ and $182^{\circ} \mathrm{C}$ $\left(117.2 \pm 31.6^{\circ} \mathrm{C}, n=52\right)$, final ice-melting temperatures from $-25.4^{\circ}$ to $-2.0^{\circ} \mathrm{C}\left(15.3 \pm 6.1^{\circ} \mathrm{C}, n=42\right)$, and salinities from 3.4 to 24.4 wt. $\%(17.9 \pm 5.5$ wt. $\%, n=43)$. The salinities are similar in D2 and C3 but slightly lower in some of the D3 samples (Fig. 6b). The mean Th values of D3 and C3 are close (about $120^{\circ}$ and $117^{\circ} \mathrm{C}$, respectively) although the $\mathrm{C} 3 \mathrm{Th}$ values have a wider range but those of D2 are lower (Fig. 6a-b). The estimates of minimum entrapment temperatures obtained from the fluid inclusion data from the Boat Harbour Formation carbonates are a similar order of magnitude to the estimates of burial temperatures (about $75^{\circ} \mathrm{C}$ ) suggested by earlier studies of conodont alteration indices (CAI), acritarch alteration indices (AAI) and graptolite reflectance from the Lower Ordovician carbonates of the Port au Port Peninsula, assuming a geothermal gradient of $25^{\circ} \mathrm{C} / \mathrm{km}$ and burial depth about $3 \mathrm{~km}$ (Nowlan and Barnes 1987; Williams et al. 1998). CAI, AAI, and graptolite reflectance record the maximum temperature event affecting the organic elements within the carbonates but as demonstrated in a recent study from nearby Anticosti Island, they will fail to record higher heat flow (hydrothermal) events if the latter is focused along specific carrier beds not sampled for petrographic examination (Lavoie et al., 2005; Lavoie and Chi, in press).

\section{Major and Trace Elements}

Table 2 summarizes the major and trace element concentrations in the main carbonate phases of the Boat Harbour Formation. Despite the general overlap in the elemental composition (Fig. 7a-b), their statistical parameters (Table 2), particularly the mean values, may still reveal some trends. The Mn concentrations increase from $70 \pm 31 \mathrm{ppm}$ in limemud (C1) to $226 \pm 129 \mathrm{ppm}$ in the latest fracture-filling cement (C3) and those of Fe from $379 \pm 264$ ppm to $3438 \pm 2288$ ppm (Table 2 and Fig. 7a), respectively. However, this is not the case for the dolomites where Mn contents vary from $289 \pm 153 \mathrm{ppm}$ in D1 to

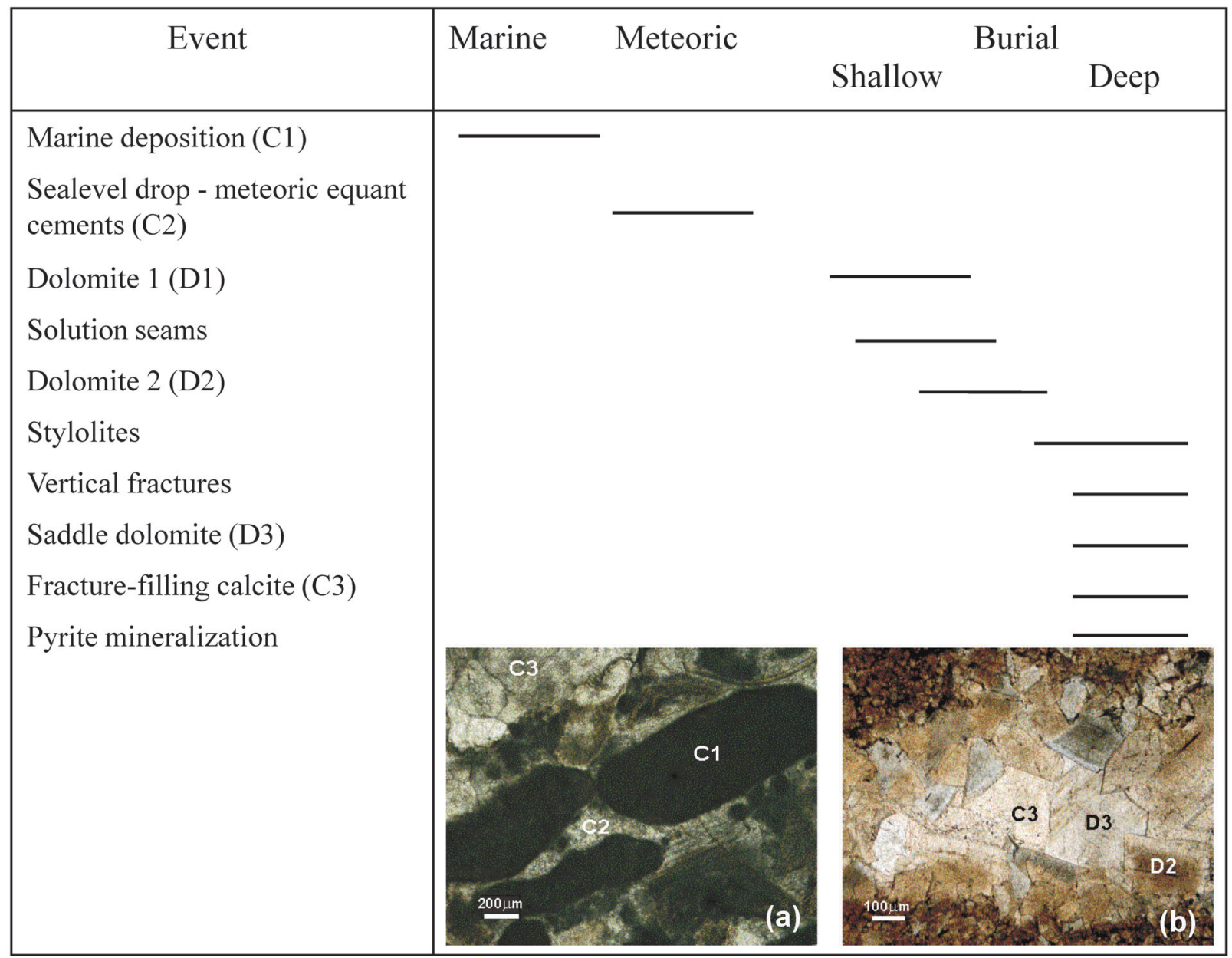

Fig. 4. Diagram showing the paragenetic sequence of the tectono-diagenetic events in the Boat Harbour Formation based on petrographic relationships. The photomicrographs at the bottom show (a) the calcite phases $\mathrm{C} 1, \mathrm{C} 2$ and $\mathrm{C} 3$ (Sample BH34; plane polarized light) and (b) the latest calcite cement (C3) postdating the latest saddle dolomite (D3) in a vug (crossed Nichols). 

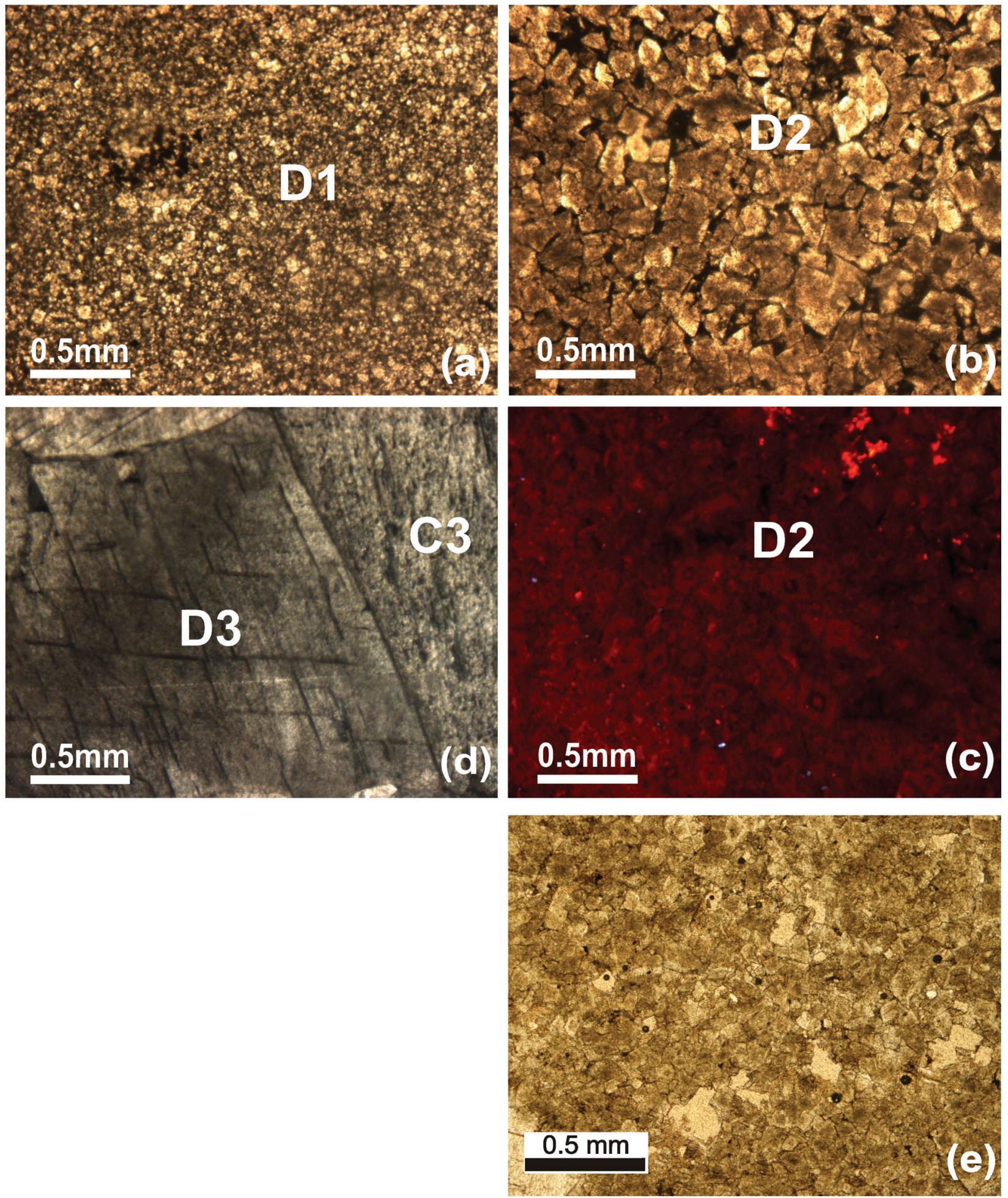

Fig. 5. Photomicrographs of the main petrographic characteristics of the Boat Harbour Formation dolomites: (a) D1 dolomicirite (plane polarized light; Sample BHA7); (b) D2 showing cloudy cores and clear rims (plane polarized; Sample BHA13); (c) Cathodoluminoscope image of (b) showing zoned luminescence in D2; (d) D3 showing typical undulose extinction (crossed Nichols; Sample BH34); and (e) preserved intercrystalline pores in D2 (plane polarized; Sample BHA35). 

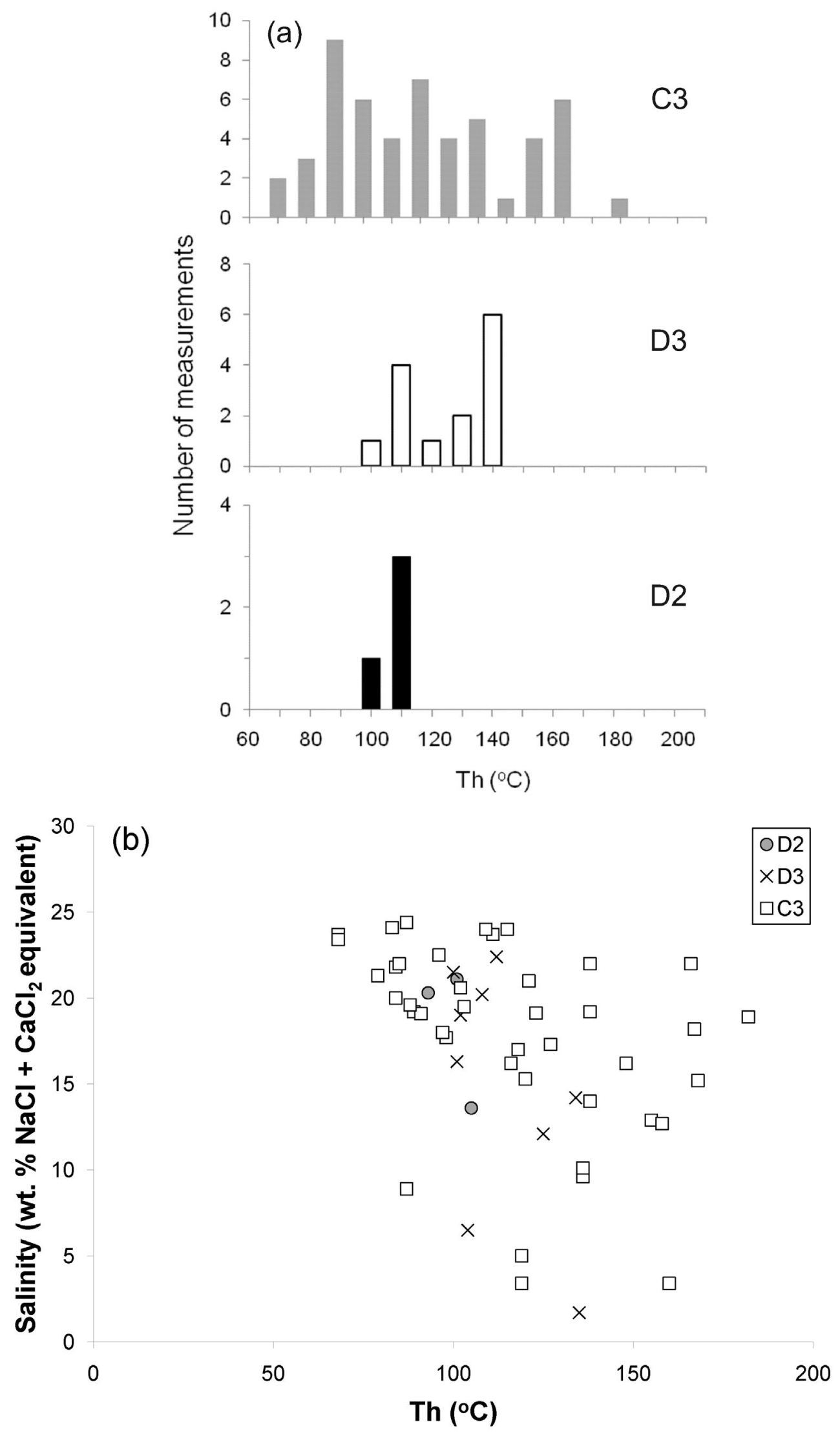

Fig. 6. Plots of the microthermometric data from fluid inclusions in the Boat Harbour Formation carbonates showing (a) histograms of homogenization temperatures and (b) a correlation scatter diagram of homogenization temperature vs final ice melting temperature. 


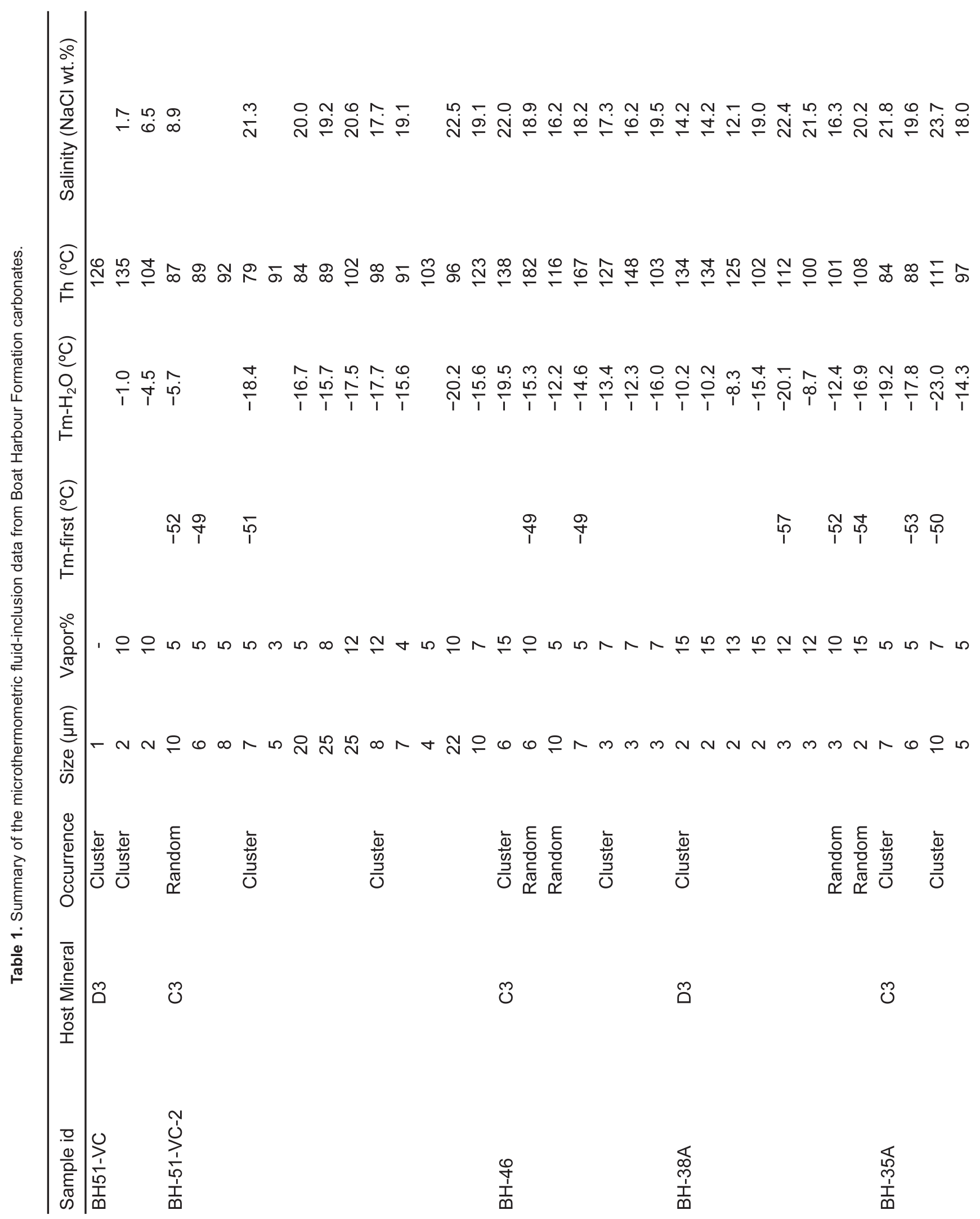




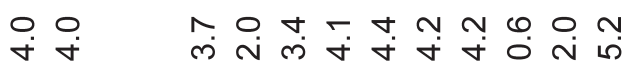

离 $\quad$ N

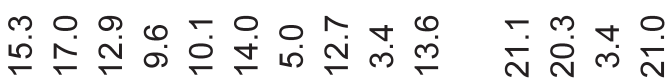

음

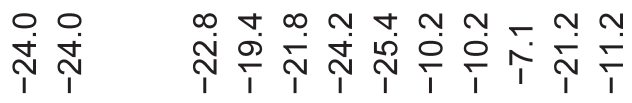

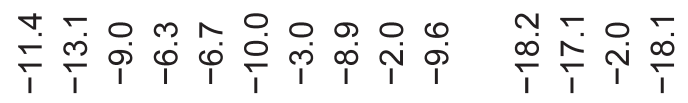

$\frac{1}{1}$

g)

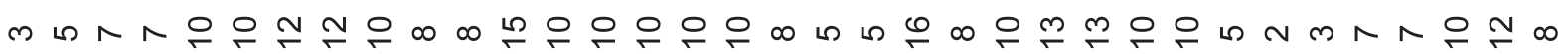

$+\infty$ L

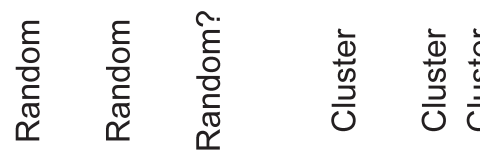

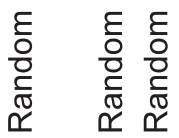

$\frac{\varepsilon}{\frac{\varepsilon}{0}}$

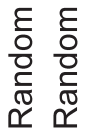

U

ดี ช

ธี

$\mathcal{O}$

志

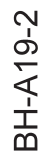

$\underset{\substack{\frac{1}{T} \\ \frac{m}{m}}}{\frac{m}{4}}$ 
Table 2. $\mathrm{CaCO}_{3}, \mathrm{MgCO}_{3}, \mathrm{Mn}, \mathrm{Sr}, \mathrm{Fe}, \delta^{18} \mathrm{O}$ and $\delta^{13} \mathrm{C}$ statistics for Boat Harbour Formation carbonates.

\begin{tabular}{|c|c|c|c|c|c|c|c|c|}
\hline Phase & & $\mathrm{CaCO}_{3} \%$ & $\mathrm{MgCO}_{3} \%$ & $\mathrm{Sr}(\mathrm{ppm})$ & $\mathrm{Mn}(\mathrm{ppm})$ & $\mathrm{Fe}(\mathrm{ppm})$ & $\delta^{13} \mathrm{C}$ & $\delta^{18} \mathrm{O}$ \\
\hline \multirow[t]{5}{*}{$\mathrm{C} 1$} & $n$ & 10.0 & 10.0 & 10 & 10 & 10 & 22.0 & 22 \\
\hline & average & 98.9 & 1.1 & 344 & 70 & 379 & -2.6 & -7.5 \\
\hline & stdev & 0.7 & 0.7 & 77 & 31 & 264 & 0.6 & 0.6 \\
\hline & $\max$ & 99.4 & 2.9 & 479 & 148 & 1002 & -1.8 & -6.0 \\
\hline & $\min$ & 97.1 & 0.6 & 242 & 38 & 100 & -4.2 & -8.5 \\
\hline \multirow[t]{5}{*}{$\mathrm{C} 2$} & $n$ & 1 & 1 & 1 & 1 & 1 & 7.0 & 7 \\
\hline & average & 99.2 & 0.8 & 392 & 165 & 264 & -2.4 & -7.7 \\
\hline & stdev & & & & & & 0.6 & 0.5 \\
\hline & $\max$ & & & & & & -1.8 & -7.1 \\
\hline & $\min$ & & & & & & -3.6 & -8.6 \\
\hline \multirow[t]{5}{*}{ C3 } & $n$ & 7 & 7 & 7 & 7 & 7 & 10.0 & 10 \\
\hline & average & 98.6 & 1.4 & 182 & 257 & 616 & -3.4 & -9.6 \\
\hline & stdev & 1.5 & 1.5 & 128 & 440 & 501 & 0.8 & 1.9 \\
\hline & $\max$ & 99.8 & 4.6 & 364 & 1247 & 1288 & -2.6 & -7.0 \\
\hline & $\min$ & 95.4 & 0.2 & 66 & 21 & 91 & -5.6 & -12.9 \\
\hline \multirow[t]{5}{*}{ D1 } & $n$ & 16 & 16 & 16 & 16 & 16 & 28.0 & 28 \\
\hline & average & 73.6 & 26.4 & 168 & 289 & 2926 & -2.1 & -6.2 \\
\hline & stdev & 3.1 & 3.1 & 45 & 153 & 1908 & 0.6 & 0.8 \\
\hline & $\max$ & 79.3 & 31.5 & 244 & 715 & 9124 & -1.0 & -4.0 \\
\hline & $\min$ & 68.5 & 20.7 & 98 & 124 & 1247 & -3.3 & -7.7 \\
\hline \multirow[t]{5}{*}{ D2 } & $n$ & 9 & 9 & 9 & 9 & 9 & 9.0 & 9 \\
\hline & average & 66.7 & 33.3 & 144 & 192 & 2221 & -2.0 & -6.5 \\
\hline & stdev & 6.6 & 6.6 & 79 & 82 & 883 & 0.8 & 0.9 \\
\hline & $\max$ & 76.7 & 42.1 & 299 & 360 & 3808 & -1.1 & -5.2 \\
\hline & $\min$ & 57.9 & 23.3 & 48 & 107 & 1089 & -3.0 & -7.9 \\
\hline \multirow[t]{5}{*}{ D3 } & $n$ & 2 & 2 & 2 & 2 & 2 & 3.0 & 3 \\
\hline & average & 73.7 & 26.3 & 117 & 254 & 3544 & -3.2 & -8.3 \\
\hline & stdev & 5.3 & 5.3 & 33 & 169 & 3225 & 1.2 & 0.9 \\
\hline & $\max$ & 77.4 & 30.0 & 140 & 373 & 5825 & -1.9 & -7.4 \\
\hline & $\min$ & 70.0 & 22.6 & 94 & 134 & 1264 & -4.3 & -9.3 \\
\hline
\end{tabular}

$254 \pm 169 \mathrm{ppm}$ in D3 but those of Fe increase from $2926 \pm 1908$ ppm to $4544 \pm 3225$ ppm (Table 2 and Fig. $7 \mathrm{a}$ ). The Sr concentrations decrease from $344 \pm 77 \mathrm{ppm}$ in $\mathrm{C} 1$ to $89 \pm 54 \mathrm{ppm}$ in $\mathrm{C} 3$ (Fig. 7b) and from $168 \pm 45 \mathrm{ppm}$ in D1 to $117 \pm 33 \mathrm{ppm}$ in D3.

Notwithstanding the general overlap of elemental composition of the carbonate phases, it is well accepted that during burial diagenesis of carbonates some elements, such as $\mathrm{Sr}$ and $\mathrm{Na}$, are depleted in the late diagenetic carbonate phase whereas others, such as Mn and Fe, are enriched (Veizer, 1983).

\section{OXYGEN AND CARbon Isotopes}

The $\delta^{13} \mathrm{C}$ and $\delta^{18} \mathrm{O}$ values of the Boat Harbour Formation calcites (Table 2 and Fig. 8) decrease from $-2.6 \pm 0.6$ to $-7.5 \pm 0.6 \%$ (VPDB) for $\mathrm{C} 1$ to $-3.4 \pm 0.8$ and $-9.6 \pm 1.9 \%$ (VPDB) for $\mathrm{C} 3$, respectively. The mean $\delta^{13} \mathrm{C}$ values of $\mathrm{D} 1$ and
D2 $(-2.1 \pm 0.6$ and $-1.9 \pm 0.8$, respectively) are statistically indistinguishable (Table 2) but those of D3 $(-3.2 \pm 1.2)$ are relatively more depleted in heavy isotope. However, their mean $\delta^{18} \mathrm{O}$ values (Table 2) decrease from $-6.2 \pm 0.8 \%$ (VPDB) in D1 to $-8.3 \pm 0.9 \%$ (VPDB) in D3.

\section{STRONTIUM IsOTOPES}

The earliest phase of dolomites (D1) yielded ${ }^{87} \mathrm{Sr} /{ }^{86} \mathrm{Sr}$ values between $0.708797 \pm 0.000006$ and $0.709908 \pm 0.000008$ (Fig. 9 and Appendix 1). The D2 dolomites yielded values that range between $0.709007 \pm 0.000006$ and $0.709335 \pm 0.000006$, which overlap with those of D1, (Fig. 9) whereas the latest dolomite (D3) has values that range between $0.708669 \pm 0.000007$ and $0.709544 \pm 0.000007$, which are slightly less radiogenic than those of D2 (Appendix 1). 

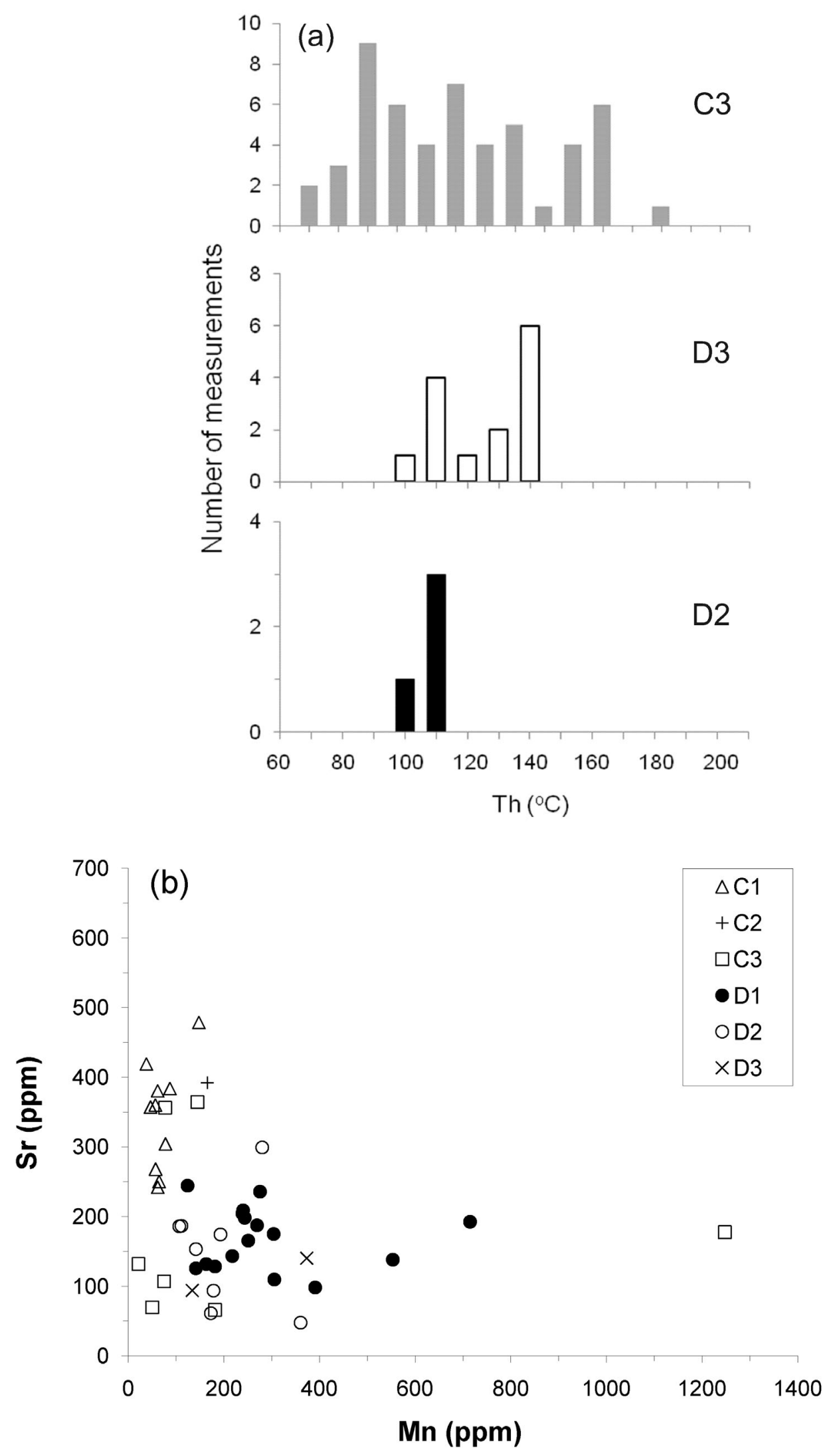

Fig. 7. Scatter diagrams of (a) $\mathrm{Mn} v s \mathrm{Fe}$ and (b) $\mathrm{Mn} v s \mathrm{Sr}$ for all carbonate phases in the Boat Harbour Formation. 


\section{$\delta^{18} \mathrm{O} \%$ (VPDB)}

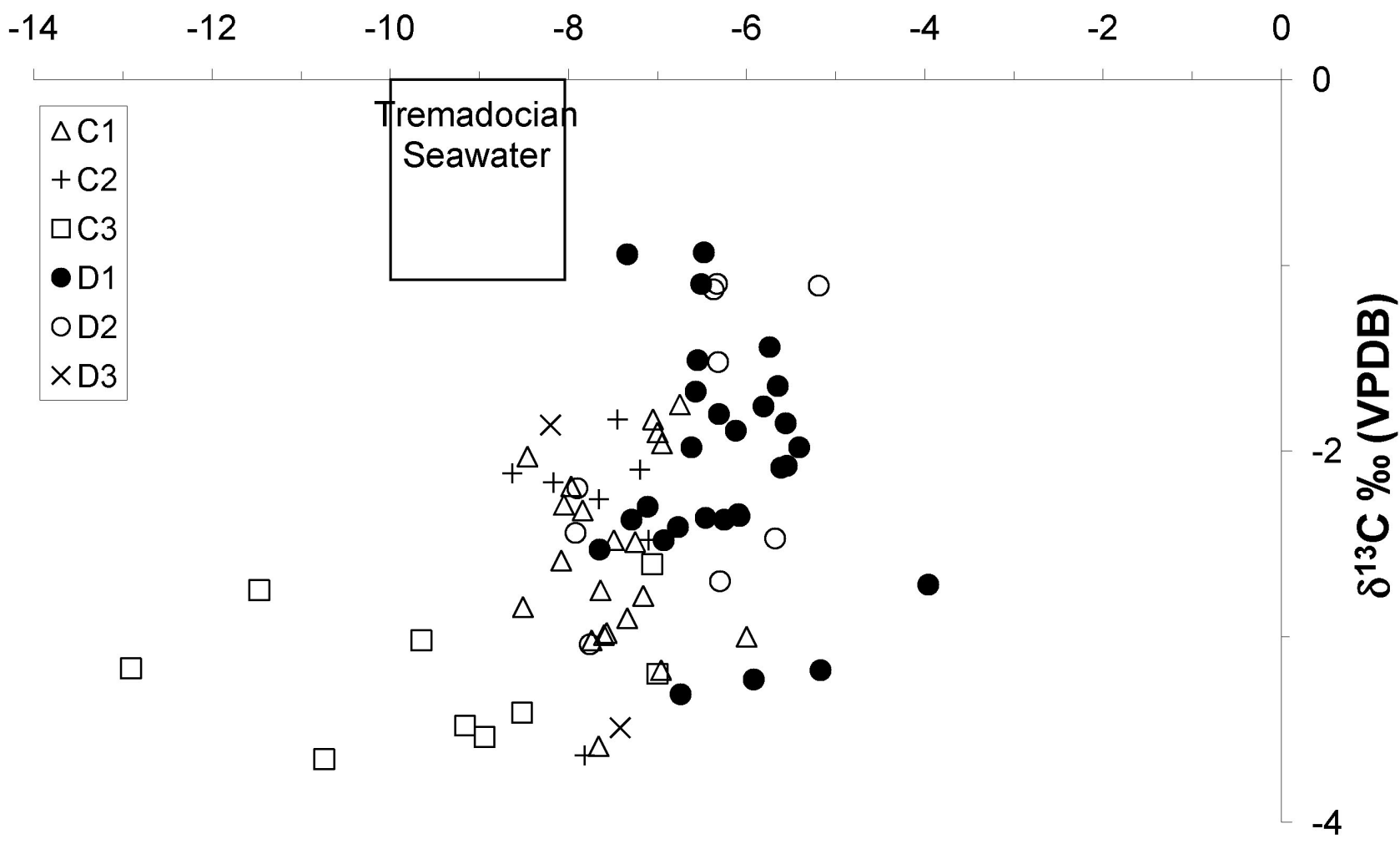

Fig. 8. Scatter diagram of $\delta^{18} \mathrm{O}$ vs $\delta^{13} \mathrm{C}$ for the different Boat Harbour Formation carbonate phases. The square represents the range of isotopic composition of best preserved carbonates precipitated from the early Ordovician (Tremadocian) seawater (cf. Shields et al., 2003).

\section{Discussion}

\section{ORIGIN OF DOLOMITES}

\section{Dolomite Petrography}

The petrographic observations of the D1 to D3 succession allow us to propose some preliminary interpretations as to their diagenetic setting. The relative fabric preservation, nearmicritic crystal size (Fig. 5a), and dull CL response of D1 suggest that it was likely a replacement of a marine limemud during an early stage of diagenesis in near-surface (low temperature) to shallow burial environments. The larger crystal size of D2 together with the fact that D2 crystals are crosscut by an early phase of solution seams (cf. Choquette and James, 1987) (Fig. 5b) may suggest a later stage of replacement but likely under shallow to intermediate burial depth and at relatively higher temperatures compared with D1. The D2 crystals exhibit distinctive zoned CL (Fig. 5c) images suggesting that the redox conditions and chemistry of the parent dolomitizing fluid varied during deposition.

The undulose extinction (Fig. 5d), dull CL images, and distinctive high $\mathrm{Fe}$ contents (up to $5825 \mathrm{ppm}$, Table 2) of the late D3 phase are all characteristics of saddle dolomite as reported in numerous studies of Phanerozoic sedimentary basins. Whatever the ultimate preferred scenario for the precipitation and/or formation of saddle dolomite, all researchers agree that this occurs under relatively high temperature from reduced saline brines (e.g. Lohman and Walker, 1989; Wendte et al., 1998; Azmy et al., 2001; Al-Aasm, 2003; Lavoie and Morin, 2004; Lonnee and Machel, 2006; Davis and Smith, 2006).

\section{Major and Trace Elements}

Elemental compositions of dolomites may provide some information about their origin and environment of deposition. The mean values of $\mathrm{Ca}$ concentrations of the Boat Harbour Formation dolomites (D1 to D3) vary from about 67 to $74 \%$ (Table 2), suggesting that these dolomites are non-stoichiometric (cf. Budd, 1997; Warren, 2000).

Trace element concentrations in dolomites, particularly those of Sr, may reflect the nature of the dolomitizing fluids (e.g. Lu and Meyers, 1998); this is particularly significant for those dolomites of the Boat Harbour Formation which do not contain remnant of precursor calcites as indicated by their low Sr-contents (48-299 ppm; Table 2) compared with those of $\mathrm{C} 1$ and $\mathrm{C} 2$ (242-479 ppm, Table 2). The $\mathrm{Sr} / \mathrm{Ca}$ molar ratio of the dolomitizing fluid can be used to investigate the origin of dolomite and its diagenetic environment (cf. Vahrenkamp and Stewart, 1990; Banner, 1995; Budd, 1997; Azmy et al., 2001). The Sr/Ca molar ratio of the dolomitizing fluids can be calculated from the 


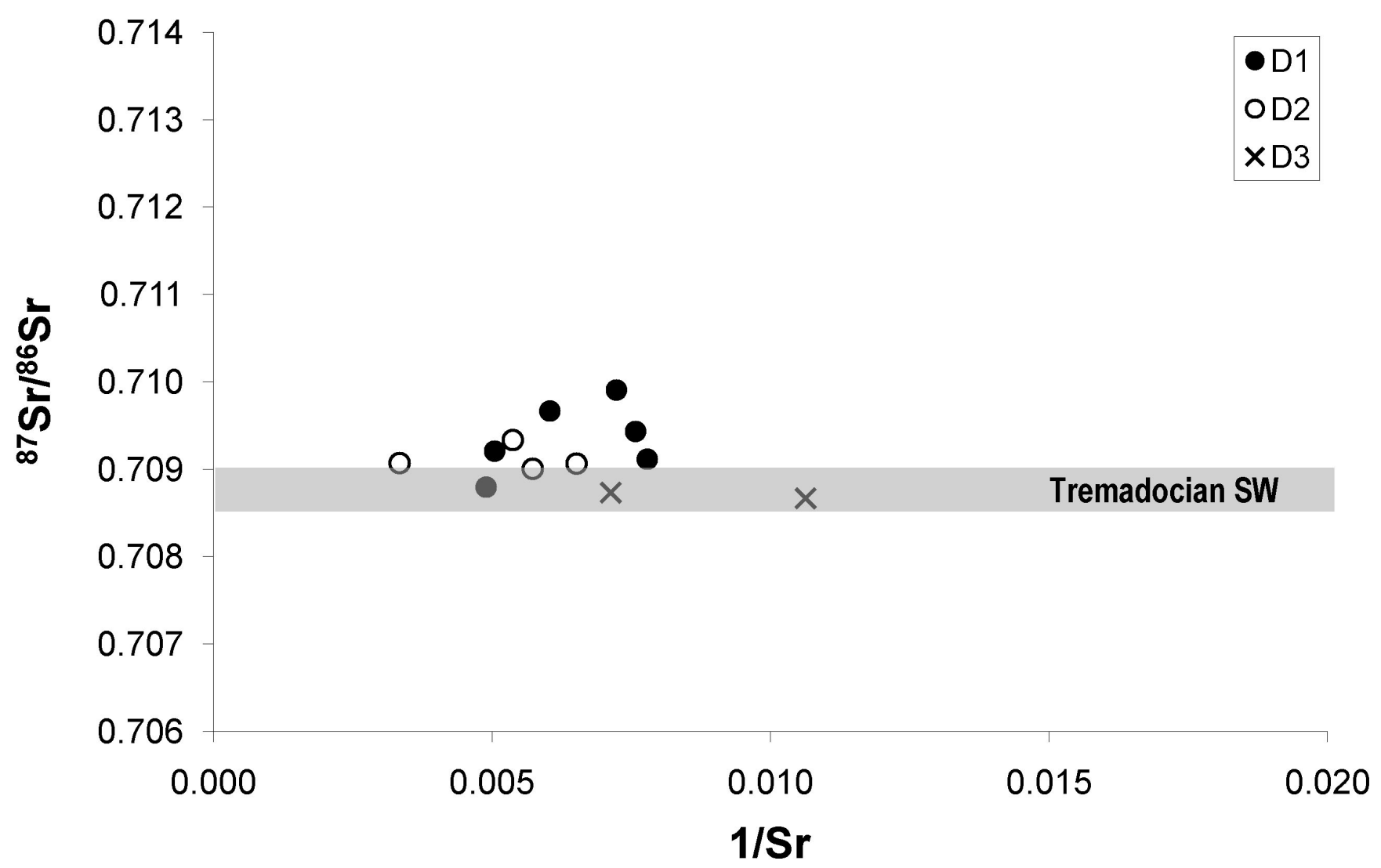

Fig. 9. Scatter diagram of $1 / \mathrm{Sr} v{ }^{87} \mathrm{Sr} /{ }^{86} \mathrm{Sr}$ values in the Boat Harbour Formation dolomites. The shaded area represents the ranges of primary ${ }^{87} \mathrm{Sr} /{ }^{86} \mathrm{Sr}$ values suggested for the Tremadocian seawaters (cf. Shields et al., 2003).

equation $(\mathrm{Sr} / \mathrm{Ca})_{\text {dolomite }}=\mathrm{D}_{\mathrm{Sr}}(\mathrm{Sr} / \mathrm{Ca})_{\text {fluid, }}$, where $\mathrm{D}_{\mathrm{Sr}}$ is the distribution coefficient of Sr between the diagenetic fluid and the precipitated dolomite (Veizer, 1983). The Boat Harbour Formation D1 phase has low Sr concentrations with an average of $168 \pm 45 \mathrm{ppm}$ (Table 2). Despite the uncertainty about the exact value of $\mathrm{D}_{\mathrm{sr}}$, the suggested values from the literature range between 0.015 and 0.06 (Veizer, 1983; Vahrenkamp and Stewart, 1990; Banner, 1995; Budd, 1997), which may yield molar $\mathrm{Sr} / \mathrm{Ca}$ ratios for the Boat Harbour Formation D1 fluids between $0.0069 \pm 0.0017$ for $\mathrm{D}_{\text {sr }}=0.015$ and $0.0017 \pm 0.0004$ for $\mathrm{D}_{\text {sr }}=0.06$. These values are significantly lower than the molar $\mathrm{Sr} / \mathrm{Ca}$ ratio of present-day seawater (0.0086; Drever, 1988), thus suggesting an early mixing of normal marine water with a $\mathrm{Sr}$-depleted fluid such as meteoric water (e.g. Azmy et al., 2001). Together with the petrographic evidences (near-micritic grain size and fabric retention), the suggested mixing of diagenetic waters indicate that D1 likely formed in a mixing zone during the early stages of near-seafloor to shallowest burial diagenesis. Such a mixing model is also consistent with the lack of evaporite interlayers in the Boat Harbour Formation.

\section{Oxygen and Carbo|sotopes}

The considerable overlap in $\delta^{13} \mathrm{C}$ values of the Boat Harbour Formation early dolomites (D1 and D2) and marine limemud (C1) (Fig. 8) may suggest that the limemud was likely the precursor of those dolomites since low $\mathrm{CO}_{2}\left(\right.$ low $\left.\mathrm{pCO}_{2}\right)$ is generally dissolved in the diagenetic waters (Land, 1992). On the other hand, the low $\delta^{13} \mathrm{C}$ values of the limemud (C1) relative to those of the best preserved calcite from Tremadocian seawater (Veizer et al., 1999; Shields et al., 2003) suggest a possible influence of organic matter and/or some input of $\delta^{13} \mathrm{C}$-depleted meteoric fluids in the early diagenetic system as also suggested by the calculated $\mathrm{Sr} / \mathrm{Ca}$ molar ratios of D1 fluids. The general narrow range of $\delta^{13} \mathrm{C}$ variations (within about 2\% VPDB) of Boat Harbour Formation carbonates suggests that the homogenous composition of the diagenetic fluid may reflect localized rather than regional sources and circulation. The depleted $\delta^{18} \mathrm{O}$ values of $\mathrm{C} 3(-9.6 \pm 1.9 \%$ VPDB $)$ compared with those of $\mathrm{C} 1$ and $\mathrm{C} 2(-7.5 \pm 0.6 \%$ and $-7.7 \pm 0.5 \%$ VPDB, respectively) reflects the effect of precipitation at higher temperature in the deep burial environment, which is consistent with the measured high $\mathrm{Th}$ values $\left(117.2 \pm 31.6^{\circ} \mathrm{C}\right)$ of the primary two-phase inclusions from C3 (Table 1). Despite the primary petrographic features of the studied two-phase inclusions (Goldstein and Reynolds, 1994) trapped in C3, they still provide a wide range of Th $\left(68\right.$ to $\left.182^{\circ} \mathrm{C}\right)$. This might be explained by tectonic uplift during the precipitation of $\mathrm{C} 3$, which likely brought the sediments to slightly shallower settings and thus resulted in entrapment of primary inclusions at different burial temperatures (e.g. Azmy et al., 2008). 


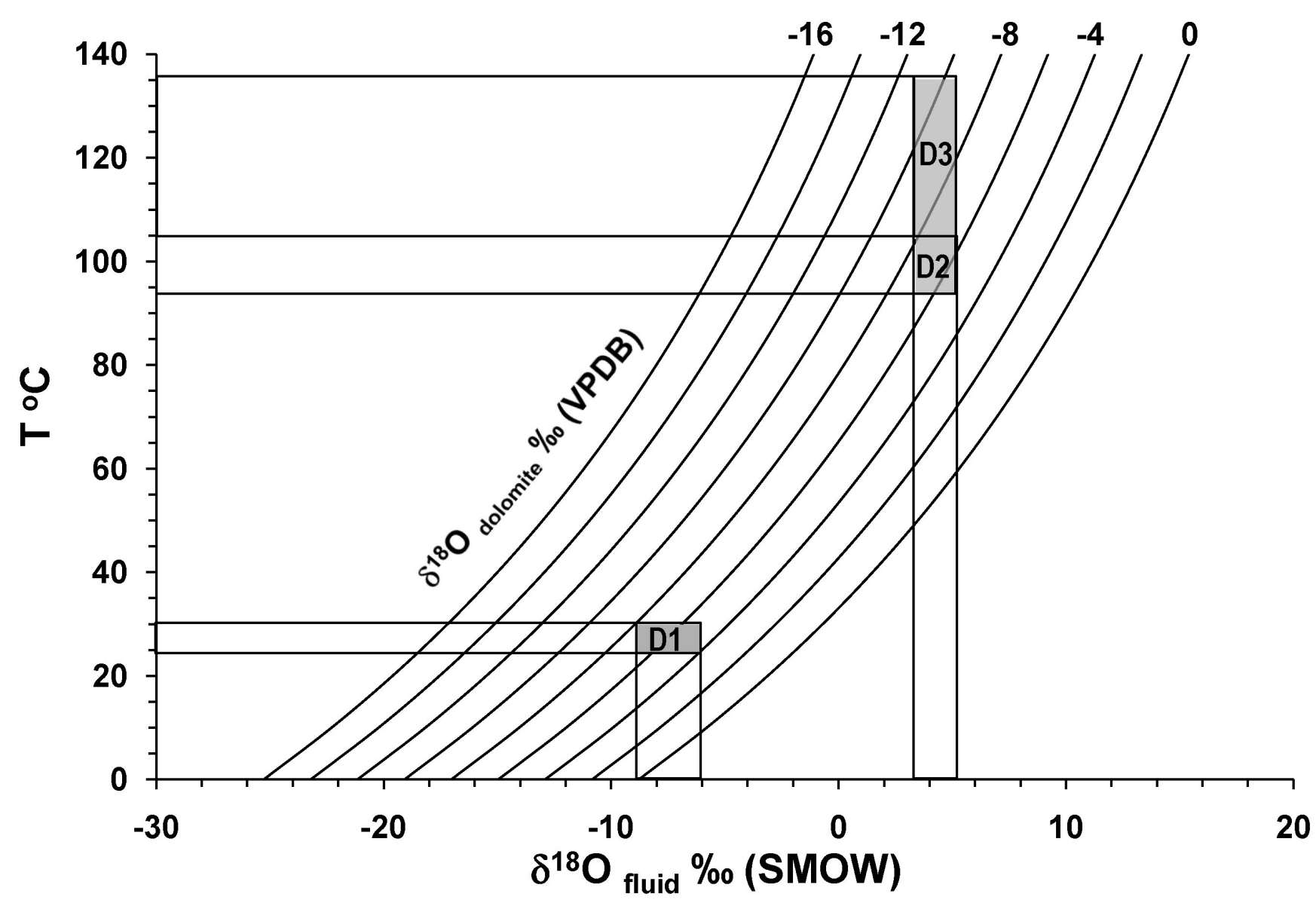

Fig. 10. Plot of Temperature vs $\delta^{18} \mathrm{O}_{\text {diagenetic fluid }}$ for various $\delta^{18} \mathrm{O}_{\text {dolomite }}$ values reconstructed from the equation $10^{3} \mathrm{In} \alpha=3.2 \times 10^{6} \mathrm{~T}-2-3.3$ (Land, 1983). The vertical bars indicate the ranges of $\delta^{18} \mathrm{O}_{\text {fluid }}$ based on the ranges of measured $\delta^{18} \mathrm{O}_{\text {dolomite }}$ values and homogenization temperatures $(\mathrm{Th})$ of each identified dolomite generation.

The Boat Harbour Formation saddle dolomites (D3) have mean $\delta^{18} \mathrm{O}$ values of $-8.3 \pm 0.9 \%$ (VPDB), which are significantly depleted relative to those of D1 and D2 and thus likely reflect precipitation either at higher temperatures and/or from fluids significantly different, in their O-isotopic composition, from those responsible for the precipitation of the D1-D2 phases (cf. Budd, 1997; Davies and Smith, 2006). The high homogenization (Th) temperatures (up to $135^{\circ} \mathrm{C}$ ) of the trapped primary two-phase fluid inclusions in $\mathrm{D} 3$ (Table 1) and the low melting temperatures $\left(\mathrm{Tm}_{\mathrm{ice}}\right.$ down to $\left.-23.4^{\circ} \mathrm{C}\right)$ characteristic of high salinity (cf. Goldstein and Reynolds, 1994) suggest a high temperature brine as source for D3.

Because dolomitization of limestones requires large volumes of Mg-rich waters, the oxygen isotopic composition of the dolomite is highly influenced by that of the dolomitizing fluid and the temperature of dolomitization (Land, 1992). The $\delta^{18} \mathrm{O}$ of the dolomitizing fluids can be estimated, providing that the temperature of dolomitization is established by other means such as measuring the Th of primary fluid inclusions (Land, 1983). The near-micritic crystal size of D1 and the interpretated meteoric fluid inputs, suggest that dolomitization started during early stages of diagenesis, presumably at near-surface temperature of about $25^{\circ}$ to $30^{\circ} \mathrm{C}$ (cf. Goldstein and Reynolds, 1994).
Therefore, given the $\delta^{18} \mathrm{O}$ of $\mathrm{D} 1$ phase (Table 2), the $\delta^{18} \mathrm{O}$ values of the dolomitizing fluid for D1 were likely between -6 and $-9 \%$ VSMOW (Fig. 10). The Boat Harbour Formation carbonate lithofacies reflect warm conditions in low latitude shallow marine environments (Knight et al., 2008). In similar modern tropical environments, the $\delta^{18} \mathrm{O}$ of meteoric water is about $4 \%$ lighter than that of the seawater (Clark and Fritz, 1997). The average $\delta^{18} \mathrm{O}$ value documented for the best preserved marine carbonates from the Tremadocian is about $-9 \%$ VPDB (Veizer et al., 1999; Shields et al., 2003), which translates to tropical seawaters of about -6 to $-5 \%$ VSMOW (Shields et al., 2003). Assuming that the difference in $\delta^{18} \mathrm{O}_{\mathrm{VSMOW}}$ composition between the Tremadocian meteoric and seawaters was similar to that of our modern environment, the $\delta^{18} \mathrm{O}$ values of the Tremadocian meteoric waters would be -10 to $-9 \%$ VSMOW. Considering the uncertainty in the values of dolomite-calcite, and dolomite-water, fractionation factors (Land, 1983, 1992; Budd, 1997), the calculated $\delta^{18} \mathrm{O}$ estimates ( -9 to $-6 \%$ VSMOW) for D1 fluids (Fig. 10) are consistent with the range of values estimated for the Tremadocian marine and meteoric waters ( -5 and $-9 \%$ VSMOW, respectively). This, with the lack of evaporite layers in the sequences, supports the mixing zone origin constrained by the trace element evidence but not 
the likelihood that the Boat Harbour Formation dolomicrites originated from evaporated brines (sabkhas) as was previously believed (Haywick, 1984; Lane, 1990).

The average Th values of the primary two-phase inclusions in D2 and D3 (101.0 \pm 5.7 and $120.1 \pm 14.6^{\circ} \mathrm{C}$, respectively; Table 1) suggest that they were formed at higher temperatures and likely derived from deeper burial fluids compared with those of D1. The estimated $\delta^{18} \mathrm{O}$ compositions of the D2 and D3 fluids (Table 2 ) are similar and range from +3 to $+5 \%$ VSMOW (Fig. 10). High temperature basinal brines of deep burial settings are commonly enriched in ${ }^{18} \mathrm{O}$ and are highly saline (cf. Goldstein and Reynolds, 1994), which is also consistent with the high salinities of D2 and D3 dolomites (Fig. 6b and Table 1).

\section{Sr-isotope Signatures}

The Sr- isotope signature in diagenetic solutions (e.g. dolomitizing fluids) is usually controlled by that of the dissolving precursor phase (Veizer, 1983; Banner, 1995). Therefore, the ${ }^{87} \mathrm{Sr} /{ }^{86} \mathrm{Sr}$ values of dolomites formed during early diagenesis should reflect the near-primary Sr-isotope composition of the original seawater particularly if the dolomite shows no significant recrystallization. The primary Sr-isotope compositions documented for Ordovician seawater indicate that Tremadocian seawater had the highest ${ }^{87} \mathrm{Sr} /{ }^{86} \mathrm{Sr}$ values of the entire Ordovician period (Veizer et al., 1999; Shields et al., 2003), a criterion that can be used to estimate the timing of dolomitization of the Boat Harbour Formation carbonates. The lack of correlation between the ${ }^{87} \mathrm{Sr} /{ }^{86} \mathrm{Sr}$ values of the earliest dolomite phase (D1) and its Sr content (Fig. 9) suggests that the primary ${ }^{87} \mathrm{Sr} /{ }^{86} \mathrm{Sr}$ signatures inherited from precursor carbonates were largely preserved. Assuming that the least radiogenic ${ }^{87} \mathrm{Sr} /{ }^{86} \mathrm{Sr}$ ratio $(0.709208 \pm 0.000007$; Appendix 1) of D1 is the best approximation of primary signatures, the earliest dolomitizing solutions would be Tremadocian modified seawater (Fig. 9), which is consistent with the petrographic and other geochemical evidences.

The ${ }^{87} \mathrm{Sr} /{ }^{86} \mathrm{Sr}$ ratios of the D2 and D3 phases either overlap or are slightly more radiogenic than that of the D1 phase (Fig. 9). This could suggest that later burial dolomitization of the Boat Harbour Formation carbonates occurred under a rockdominated system with Tremadocian carbonate phases buffering the ${ }^{87} \mathrm{Sr} /{ }^{86} \mathrm{Sr}$ and $\delta^{13} \mathrm{C}$ ratios of the late diagenetic phases.

\section{Development of Secondary Porosity, Reservoir Potential and Regional Considerations}

Secondary porosity plays a significant role in the evolution of hydrocarbon reservoirs. The preserved porosity occurs in the Boat Harbour Formation dolomites suggesting that it is mainly related to dolomitization (e.g. Dravis, 1992; Esteban and Taberner, 2003; Wierzbicki et al., 2006). Most of the pores are intercrystalline (50 to $200 \mu \mathrm{m}$ ) and mainly associated with the D2 replacement phase (Fig. 5e). Smooth-edged dissolution vugs (up to $400 \mu \mathrm{m}$ ) are also scattered in the dolostones. Some of the vugs and intercrystalline pores (Fig. 4b) are filled with D3 (late saddle dolomite) and C3 (latest fracture-filling calcite cements). The $\mathrm{C} 3$ cement occludes many of the pores and likely originated from late-stage non-ferroan Ca-rich fluids. The most depleted $\delta^{18} \mathrm{O}$ values measured in the $\mathrm{C} 3$ (Fig. 8 and Appendix 1) are consistent with the suggested late-stage deep burial diagenetic origin.

The visual estimates from thin sections suggest that porosity varies from $<1$ to $10 \%$. The highest porosity was observed in a zone about $5 \mathrm{~m}$-thick immediately below the upper Boat Harbour Disconformity (Fig. 2). In general, however, porosity in the rest of the formation is very low. The development of the porosity below the upper disconformity suggests that its location is linked to diagenesis occurring within the underlying carbonates. Subaerial exposure associated with the disconformity (Knight et al., 2008) might have enhanced porosity in the underlying rocks and consequently the fluid migration. This led to pervasive dolomitization of the sub-disconformity carbonates and likely provided pathways for the late secondary circulation of high temperature (hydrothermal?) brines. The preservation of intercrystalline pores in D2 below the upper disconformity suggests that later dolomitizing solutions may have come from a restricted source under semi-closed to closed conditions so that many of the developed pores remained open after dolomitization. The difference in molar volume caused by the replacement of precursor calcite (C1 and C2) with dolomite (D2), under closed system conditions, likely played a role in the development of D2-associated porosity (e.g. Azmy et al., 2008). This may also explain the lack of intercrystalline pores in some of the D2 that possibly developed by recrystallization of precursor D1.The occurrence of the latest calcite $(\mathrm{C} 3)$ after the precipitation of the late saddle dolomite (D3) in pores may imply emplacement of hot $\left(>120^{\circ} \mathrm{C}\right)$ hydrothermal or possibly acidic solutions that resulted in the development of vugs by dissolution (e.g. Wierzbicki et al., 2006). The most depleted $\delta^{18} \mathrm{O}$ values measured in $\mathrm{C} 3$ (Fig. 8 and Appendix 1) are consistent with the suggested late-stage deep burial diagenetic origin. Fractures appear to be entirely occluded with late cements (e.g. Al-Aasm and Azmy, 1996) and, therefore, played no role in the net porosity of the rocks.

Because the highest porosity in the Boat Harbour Formation dolomites is physically associated with subaerial unconformities, this may parallel to a similar relationship that was recently documented for the Aguathuna Formation (Azmy et al., 2008) at the top of the St. George Group. In both formations, dolomitization started during very shallow burial from possibly mixed marine and meteoric fluids and was followed by late high temperature dolomitization, which was not dominant.

On nearby Anticosti Island, Québec, the Lower Ordovician (Arenigian/Floian) Romaine Formation, resting unconformably on basement (Lavoie et al., 2005; Lavoie and Chi, in press), is a facies and time correlative unit of the Arenig megacycle of the St. George Group (Knight and James, 1987; Knight et al., 2007). Peritidal carbonates of the Grand-Ile Member (Lavoie et al., 2005), similar to those of the Aguathuna Formation occur at the top of the Québec sequence. Early dolomitization of the carbonate facies in the Romaine Formation is overprinted by later dolomitization events (D2 and D3 of Lavoie et al., 2005), which occurred under a fluiddominated, open diagenetic system (Lavoie and Chi, in press). 
A regional unconformity at the top of the Romaine Formation is equivalent to that of the St. George Unconformity, forming the Sauk-Tippecanoe sequence boundary in eastern Canada (James et al., 1989). In contrast to western Newfoundland, karstic dissolution of the facies immediately underlying the unconformity on Anticosti is minor and there is no obvious increase in dolomitization in the unconformity-adjacent facies. Moreover, no significant evidence for meteoric waters was detected by the various geochemical tracers $\left(\delta^{13} \mathrm{C}\right.$, Tm-ice) for all analyzed dolomite phases in Québec (Lavoie et al., 2005; Lavoie and Chi, 2006). Instead, the pore-filling and replacement D2 and D3 (saddle dolomite) phases were characterized by higher Th values (Lavoie et al, 2005) and by more radiogenic ${ }^{87} \mathrm{Sr} r{ }^{86} \mathrm{Sr}$ ratios (Lavoie and Chi, in press). This may suggest significant interactions of a $\mathrm{Mg}$-charged hot brine with a $\mathrm{Sr}$ radiogenic-enriched basement (Grenvillian basement) and that rock-buffering of $\mathrm{Sr}$ radiogenic isotopes is absent (Lavoie and Chi, in press).

Thus, the petrographic and geochemical data from the dolomites of the Romaine Formation on Anticosti Island (Lavoie et al., 2005; Lavoie and Chi, in press) are significantly different from those of the Aguathuna and Boat Harbour formations in western Newfoundland (Azmy et al., 2008 and this study, respectively). Also, even though the parageneses of the two successions are relatively similar (early near seafloor dolomites - D1, burial dolomites - D2, and saddle dolomite D3), the relative abundance of each phase differs in each area and the fluids responsible for their formation and/or precipitation were different. The main dolomitization (D2 and D3 phases) of the Romaine Formation proceeded under a fluiddominated system in the presence of very high temperature brine that interacted with the underlying crystalline basement. On the contrary, the main dolomitization of the St. George Group carbonates (D2 and D3 phases) occurred in rock-dominated environments (similar calculated estimates of $\delta^{18} \mathrm{O}$ values for D2 and D3 fluids, Fig. 10) in the presence of a high-temperature brine that did not significantly interact with any $\mathrm{Sr}$ radiogenic-enriched succession, such as Grenvillian basement. This probably reflects in part the stratigraphic position of the St. George Group which is one kilometre and more above basement, as well as the different tectonic settings of the two areas.

The Romaine Formation does not record any significant compression, although Taconian and Acadian (?) orogenies were possibly responsible for formation and reactivation of new and older (Grenvillian basement-rooted) extensional faults. Also, in the Anticosti Basin, all the petrographic, geochemical and tectonic evidences point to a "classical" hydrothermal dolomitization model as proposed for many Ordovician successions in eastern North America (Lavoie et al., 2005; Smith, 2006; Lavoie and Chi, in press). The carbonates of the St. George Group in the Port au Port Peninsula of western Newfoundland were initially significantly exhumed and karstified in early Middle Ordovician and, after some burial, the platform carbonate was involved in major compressive thin-skin (Taconian) and thick-skin (Acadian) deformation followed by later transtensional and transpressional faulting in the Carboniferous (Stockmal et al., 1998; Cooper et al., 2001). In the Port au Port Peninsula, this tectonic framework resulted in circulation of hydrothermal brines under a relatively closed diagenetic (rock-dominated) system. Elsewhere in northwestern Newfoundland near Port au Choix and Daniels Harbour, Ordovician carbonates show a clear history of faulting and deformation affecting not only the karst associated with the St. George Unconformity (Knight, 1991; Knight et al., 1991, 2007) but also the location of a significant regional, hydrothermal dolomitization. The hydrothermal dolomitization events in western Newfoundland led to the development of hydrocarbon reservoirs at Port au Choix (now exhumed; Baker and Knight, 1993; Cooper et al., 2001) and base metal mineralization at Daniels Harbour (Lane, 1990).

\section{Conclusions}

Dolostones in the Boat Harbour Formation occur commonly as units capping small-scale shallowing upward parasequences and as decimetre-thick intervals pervasively replacing carbonates below two regional disconformities. Petrographic, microthermometric, and geochemical studies of the Boat Harbour Formation carbonates suggest three major dolomitization events: 1) an early fabric-retentive episode (D1); 2) a later replacive episode (D2) of mid burial settings (mean $\mathrm{Th}=$ $101^{\circ} \mathrm{C}$ ); and, 3) a latest pore-filling to replacive saddle dolomite cement $(\mathrm{D} 3)$ of deep burial settings (mean $\mathrm{Th}=120^{\circ} \mathrm{C}$ ).

The insignificant recrystallization and near-micritic crystal size of D1 suggest that dolomitization started at an early stage of diagenesis at near surface conditions. Geochemical investigations indicate that D1 was possibly deposited in a mixingzone environment from parent fluids with $\delta^{18} \mathrm{O}$ estimated at about -9 to $-6 \%$ (SMOW). However, later phases of dolomitization (D2 and D3) suggest formation under mid- to deep burial conditions, respectively, at higher temperatures between 93 and $135^{\circ} \mathrm{C}$, likely from ${ }^{18} \mathrm{O}$-enriched hot and saline brines.

Visual estimates of porosity indicate a porous zone $(\varnothing=5$ to $10 \%$ ) of about $5 \mathrm{~m}$ thickness immediately below the Boat Harbour Disconformity, where pores (intercrystalline and vugs) are mainly associated with D2. The occurrence of pore-filling latest calcite cements suggests late introduction of Ca-rich and acidic hydrothermal fluids that possibly contributed to dolomite dissolution and development of vugs.

The dolomitization processes recorded in the Boat Harbour Formation are fairly similar to those described for the stratigraphically-overlying Aguathuna Formation, with a seemingly critical role for subaerial unconformities in controlling abundance of porous dolomites. The Romaine Formation of the nearby Anticosti basin is coeval with the Aguathuna Formation, although the former has recorded the circulation of significant volumes of high temperature saline fluids that are responsible for a higher percentage of late saddle dolomite in the Anticosti succession. Differences in tectonic settings (distal extensional foreland for Anticosti and proximal compressive foreland stacks for the Port au Port Peninsula) likely played a critical role in the different relative abundance and geochemistry of petrographically similar dolomites in both areas. 


\section{ACKNOWLEDGMENTS}

The authors wish to thank Dr. Sébastien Castonguay for his initial review of the manuscript. Our gratitude is also extended to Drs. Nick Wilson, Greg Lynch, Brian Jones and Robert B. MacNaughton for their constructive reviews and Mr. Sze Shan Yip for his help in the fluid-inclusion microscopy. This project was financed by the Earth Science Sector of Natural Resources Canada (GSC Contribution \#20080252) and by the Department of Natural Resources and Mines of Newfoundland and Labrador. Support from Vulcan Minerals Inc., Canada (to Karem Azmy), and by the Natural Sciences and Engineering Research Council of Canada (to Guoxiang Chi) is warmly acknowledged.

\section{REFERENCES}

Al-Aasm, I. 2003. Origin and characterization of hydrothermal dolomite in the Western Canada Sedimentary Basin. Journal of Geochemical Exploration, v. 78-79, p. 9-15.

and Azmy, K. 1996. Diagenesis and evolution of microporosity of Middle-Upper Devonian Kee scarp reefs, Norman Wells, N.W.T, Canada: petrographic and chemical evidence. American Association of Petroleum Geologists Bulletin, v. 80, p. 82-100.

and Clarke, J. D. 2004. The effect of hydrothermal fluid flow on early diagenetic dolomitization: an example from the Devonian Slave Point Formation, northwest Alberta, Canada. American Association of Petroleum Geologists Bulletin Hedberg Series, v. 1, p. 297-316.

Azmy, K., Veizer, J., Wenzel, B., Bassett, M. and Copper, P. 1999. Silurian strontium isotope stratigraphy. Geological Society of America Bulletin, v. 111, p. $475-483$.

, Veizer, J., Misi, A., De Olivia, T., Sanches, A.L. and Dardenne, M. 2001. Isotope stratigraphy of the Neoproterozoic carbonate of Vazante Formation Saõ Francisco Basin, Brazil. Precambrian Research, v. 112, p. 303-329.

Lavoie, D., Knight, I. and Chi, G. 2008. Dolomitization of the Aguathuna Formation carbonates of Port au Port Peninsula in western Newfoundland, Canada: implications for a hydrocarbon reservoir. Canadian Journal of Earth Sciences, v. 45, p. 795-813.

Baker, D. and Knight, I. 1993. The Catoche dolomite project, Anticosti Basin, eastern Canada: CERR Report, Memorial University of Newfoundland, St. John's, Newfoundland, $174 \mathrm{p}$.

Banner, J.L. 1995. Application of the trace element and isotope geochemistry of strontium to studies of carbonate diagenesis. Sedimentology, v. 42, p. $805-824$

Budd, D.A. 1997. Cenozoic dolomites of carbonate islands: their attributes and origin. Earth-Science Reviews, v. 42, p. 1-47.

Boyce, W.D. and Stouge, S. 1997. Trilobites and conodont biostratigraphy of the St. George Group at Eddies Cove West, western Newfoundland. Current Research. Newfoundland Department of Mines and Energy. Geological Survey, Report 97-1, p. 183-200.

Chi, G. and Ni, P. 2007. Equations for calculation of $\mathrm{NaCl} /\left(\mathrm{NaCl}+\mathrm{CaCl}_{2}\right)$ ratios and salinities from hydrohalite-melting and ice-melting temperatures in the $\mathrm{H}_{2} \mathrm{O}-\mathrm{NaCl}-\mathrm{CaCl}_{2}$ system. Acta Petrologica Sinica, v. 22, p. 33-37.

Choquette, P.W. and James, N.P. 1987. Diagenesis in limestones-3. The deep burial environment. Geoscience Canada, v. 14, p. 3-36.

Clark, I.D. and Fritz, P. 1997. Environmental Isotopes in Hydrogeology. Lewis publisher, Boca Raton, New York, 328 p.

Coleman, M.L., Walsh, J.N. and Benmore, R.A. 1989. Determination of both chemical and stable isotope composition in milligram-size carbonate samples. Sedimentary Geology, v. 65, p. 233-238.

Cooper, M., Weissenberger, J., Knight, I., Hostad, D., Gillespie, D., Williams, H., Burden, B., Porter-Chaudhry, J., Rae, D. and Clark, E. 2001. Basin evolution in western Newfoundland: New insights from hydrocarbon exploration. American Association of Petroleum Geologists Bulletin, v. 85, p. $393-418$

Davies, G.R. and Smith, L.B. 2006. Structurally controlled hydrothermal dolomite reservoir: an overview. The American Association of Petroleum Geologists Bulletin, v. 90, p. 1641-1690.

Dickson, J.A.D. 1966. Carbonate identification and genesis as revealed by staining. Journal of Sedimentary Petrology, v. 36, p. 491-505.

Dravis, J.J. 1992. Burial dissolution in limestones and dolomites - criteria for recognition and discussion of controls: a case study approach (part 1): Upper Jurassic Haynesville limestones, east Texas; part 2: Devonian Upper Elk Point dolomites, western Canada: American Association of Petroleum Geologists-Canadian Society of Petroleum Geologists Short Course on Subsurface Dissolution Porosity in Carbonates, Calgary, Canada, $171 \mathrm{p}$.

Drever, J.I. 1988. The Geochemistry of Natural Waters. Prentice Hall Inc., Englewood Cliffs, N. J., 437 p.

Esteban, M. and Taberner, C. 2003. Secondary porosity development during late burial in carbonate reservoirs as a result of mixing and/or cooling of brines. Journal of Geochemical Exploration, v. 78-79, p. 355-359.

Fowler, M.G., Hamblin, A.P., Hawkins, D., Stasiuk, L.D. and Knight, I. 1995. Petroleum geochemistry and hydrocarbon potential of Cambrian and Ordovician rocks of western Newfoundland. Bulletin of Canadian Petroleum Geology, v. 43, p. 187-213.

Goldstein, R.H. and Reynolds, T.J. 1994. Systematics of fluid inclusions in diagenetic minerals. Short course 31, SEPM (Society for Sedimentary Geology), 199 p.

Haywick, D.W. 1984. Dolomite within the St. George Group (Lower Ordovician), western Newfoundland. Unpublished M.Sc. thesis, Memorial University of Newfoundland, St. John's Newfoundland. $281 \mathrm{p}$.

James, N.P., Stevens, R.K., Barnes, C.R. and Knight, I. 1989. Evolution of a Lower Paleozoic continental-margin carbonate platform, northern Canadian Appalachians. In: Controls on Carbonate Platform and Basin Development. P. D. Crevello, J. L. Wilson, J. F. Sarg and J. F. Read (eds.). Society of Economic Paleontologists and Mineralogists Special Publication, v. 44, p. 123-146.

Ji, Z. and Barnes, C.R. 1993. A major conodont extinction event during the Early Ordovician within the Midcontinent Realm. Palaeoceanography, Plalaeoclimatology, Palaeoecology, v. 104, p. 37-47.

Knight, I. 1991. Geology of Cambro-Ordovician rocks in the Port Saunders (NTS 12I/11), Castors River (NTS12I/15), St. John Island (NTS 12I/14) and Torrent River (NTS 121/10) map areas. In: Newfoundland Department of Mines and Energy, Mineral Development Division, Report 91-4, R.F. Blackwood, C.P.G. Pereira, and D.G. Walsh (eds.). 138 p.

and James, N.P. 1987. Stratigraphy of the St. George Group (Lower Ordovician), western Newfoundland: the interaction between eustasy and tectonics. Canadian Journal of Earth Sciences, v. 24, p. 1927-1952.

, James, N.P. and Lane, T.E. 1991. The Ordovician St. George Unconformity, northern Appalcachians: the relationship of plate convergence at the St. Lawrence Promontory to the Sauk/Tippecanoe sequence boundary. Geological Society of America Bulletin, v. 103, p. 1200-1225.

, Azmy, K., Greene, M. and Lavoie, D. 2007. Lithostratigraphic setting of diagenetic, isotopic, and geochemistry studies of Ibexian and Whiterockian carbonates of the St. George and Table Head groups in western Newfoundland. Current Research Newfoundland and Labrador Department of Natural Resources Geological Survey. Report 07-1, p. 55-84. Azmy, K., Boyce, D. and Lavoie, D. 2008. Tremadocian carbonates of the lower St. George Group, Port au Port Peninsula, western Newfoundland: lithostratigraphic setting of diagenetic, isotopic, and geochemistry studies. Current Research. Newfoundland and Labrador Department of Natural Resources Geological Survey. Report 08-1, p. 1-43.

Land, L.S. 1983. The application of stable isotopes to studies of the origin of dolomite and to problems of diagenesis of clastic sediments. In: Stable isotopes in sedimentary geology. M.A. Arthur, T.F. Anderson, I.R. Kaplan, J. Veizer and L.S. Land (eds.). SEPM Short Course Notes 10, p. 4-1-4-22.

1992. The dolomite problem: stable and radiogenic isotope clues, In: Isotopic signature of sedimentary records. N. Clauer and S. Chaudhuri (eds.). Lecture Notes in Earth Science, v. 43, p. 49-68. 
Lane, T.E. 1990. Dolomitization, brecciation and zinc mineralization and their paragenetic, stratigraphic and structural relationships in the upper St. George Group (Ordovician) at Daniel's Harbour, western Newfoundland: Unpublished PhD Thesis, Memorial University of Newfoundland, $496 \mathrm{p}$. 1992. The dolomite problem: stable and radiogenic isotope clues. In: Isotopic signature of sedimentary records. N. Clauer and S. Chaudhuri (eds.). Lecture Notes in Earth Science, v. 43, p. 49-68.

Lavoie, D. 2008. Appalachian Foreland Basin: 1-Canada. In: Sedimentary basins of the USA and Canada. A.D. Miall (ed.). Elsevier Science Publishing, p. 63-105.

and Morin, C. 2004. Hydrothermal dolomitization in the Lower Silurian Sayabec Formation in northern Gaspé - Matapédia (Québec): constraints on timing of porosity and regional significance of hydrocarbon reservoirs. Bulletin of Canadian Petroleum Geology, v. 52 (3), p. 256-269. and Chi, G. 2006. Hydrothermal dolomitization in the Lower Silurian La Vieille Formation in northern New Brunswick: geological context and significance for hydrocarbon exploration. Bulletin of Canadian Petroleum Geology, v. 54, p. 380-395. and in press. Lower Paleozoic foreland basins in eastern Canada: tectono-thermal events recorded by faults, fluids and hydrothermal dolomites. Bulletin of Canadian Petroleum Geology.

Brennan-Alpert, P. and Betrand, R. 2005. Hydrothermal

dolomitization in the Lower Ordovician Romaine Formation of the Anticosti Basin: significance for hydrocarbon exploration. Bulletin of Canadian Petroleum Geology, v. 53, p. 454-471.

Langdon, G.S. and Mireault, R. 2004. Revised exploration model for the inversion fairway, western Port au Port, Penensula, Newfoundland: a report for Canadian Imperial Venture Corp., St. John's, Newfoundland. 50 p. http://www.canadianimperial.net/

Lohman K.C. and Walker, J.C.G. 1989. The $\delta^{18} \mathrm{O}$ record of Phanerozoic abiotic marine calcite cements. Geophysical Research Letters, v. 16, p. 319-322.

Lonnee, J. and Machel, H.G. 2006. Pervasive dolomitization with subsequent hydrothermal alteration in the Clarke Lake gas field, Middle Devonian Slave Point Formation, British Columbia, Canada. American Association of Petroleum Geologists Bulletin, v. 90, p. 1739-1761.

Lu, F.H., and Meyers, W.J. 1998. Massive dolomitization of Late Miocene carbonate platform: a case of mixed evaporate brines with meteoric water, Nijar, Spain. Sedimentology, v. 45, p. 263-277.

Machel, H.G. and Mountjoy, E.W. 1986. Chemistry and environments of dolomitization - a reappraisal. Earth-Science Reviews, v. 23, p. 175-202. and Mountjoy, E.W. 1990. Coastal mixing zone dolomite, forward modelling, and massive dolomitization of platform-margin carbonateDiscussion. Journal of Sedimentary Petrology, v. 60, p. 1008-1012.

McArthur, J.M. 1994. Recent trends in strontium isotope stratigraphy. Terra Nova, v. 6, p. 331-358.

Nowlan, G.S. and Barnes, C.R. 1987. Thermal maturation of Paleozoic strata in Eastern Canada from conodont colour alteration index (CAI) data with implications for burial history, tectonic evolution, hotspot tracks and mineral and hydrocarbon exploration. Bulletin - Geological Survey of Canada, $367 \mathrm{p}$.

Pratt, B.R. and James, N.P. 1986. The tidal flat island model for peritidal shallow-upward sequences; St. George Group, western Newfoundland. Sedimentology, v. 33, p. 313-344.
Shields, G.A., Carden, G.A.F., Veizer, J., Meidla, T., Rong, J-Y. and Li, R-Y. 2003. Sr, C, and O isotope geochemistry of Ordovician brachiopods: a major isotopic event around the Middle-Late Ordovician transition. Geochimica et Cosmochimica Acta, v. 67, p. 2005-2025.

Sibley, D.F. 1982. Origin of common dolomite fabrics: clues from the Pliocene. Journal of Sedimentary Petrology, v. 52, p. 1087-1100.

Smith, L.B. 2006. Origin and reservoir characteristics of Upper Ordovician Trenton-Black River hydrothermal dolomite reservoirs in New York. Bulletin of the American Association of Petroleum Geologists, v. 90, p. 1691-1718.

Stockmal, G.S., Slingsby, A. and Waldron, J.W.F. 1998. Deformation styles at the Appalachian structural front, western Newfoundland: implications of new industry seismic reflection data. Canadian Journal of Earth Sciences, v. 35 , p. $1288-1306$.

Vahrenkamp, V.C. and Stewart, P.K. 1990. A new distribution coefficient for the incorporation of strontium into dolomite and its implications for the formation of ancient dolomites. Geology, v. 18, p. 387-391.

van Staal, C.R. 2005. The Northern Appalachians. In: Encyclopedia of Geology. R.C. Selley, L. Robin, M. Cocks and I.R. Plimer (eds.). Elsevier, Oxford, v. 4, p. 81-91.

Veizer, J. 1983. Chemical diagenesis of carbonates: theory and application of trace element technique. In: Stable Isotopes in Sedimentary Geology. M.A. Arthur, T.F. Anderson, I.R. Kaplan, J. Veizer, and L.S., Land (eds.). Society of Economic Paleontologists and Mineralogists Short Course Notes 10, p. III-1-III-100.

, Ala, D., Azmy, K. , Bruckschen, P. , Bruhn, F., Buhl, D., Carden, G., Diener, A., Ebneth, S., Goddris, Y., Jasper, T., Korte, C., Pawellek, F., Podlaha, O. and Strauss, H. 1999. ${ }^{87} \mathrm{Sr} /{ }^{86} \mathrm{Sr}, \delta^{18} \mathrm{O}$ and $\delta^{13} \mathrm{C}$ evolution of Phanerozoic seawater. Chemical Geology, v. 161, p. 59-88.

Warren, J. 2000. Dolomite: occurrence, evolution, and economically important associations. Earth-Science Reviews, v. 52, p. 1-81.

Wendte, J.C., Qinq, H., Dravis, J.J., Moore, S.O., Stasiuk, L.L. and Ward, J. 1998. High-temperature saline (thermoflux) dolomitization of Devonian Swan Hills platform and bank carbonates, Wild River area, west-central Alberta: Bulletin of Canadian Petroleum Geology, v. 46, p. 210-265.

Williams, S.H., Burden, E.T. and Mukhopadhyay, P.K. 1998. Thermal maturity and burial history of Paleozoic rocks in western Newfoundland. Canadian Journal of Earth Sciences, v. 35, p. 1307-1322.

White, T. and Al-Aasm, I.S. 1997. Hydrothermal dolomitization of the Mississippian Upper Debolt Formation, Sikanni gas field, northern British Colombia, Canada. Bulletin of Canadian Petroleum Geology, v. 45, p. 297-316.

Wierzbicki, R., Dravis, J.J., Al-Aasm, I. and Harland, N. 2006. Burial dolomitization and dissolution of Upper Jurassic Abenaki platform carbonates, Deep Panuke reservoir, Nova Scotia, Canada. American Association of Petroleum Geologists Bulletin, v. 90, p. 1843-1861.

Manuscript received: June 20, 2008

Date accepted: March 24, 2009

Associate Editor: Nick Wilson 
Appendix 1. Samples, description, elemental and isotopic geochemical compositions in Boat Harbour Formation carbonates.

\begin{tabular}{|c|c|c|c|c|c|c|c|c|c|c|c|}
\hline Sample id \# & Phase & Depth (m) & $\mathrm{CaCO}_{3} \%$ & $\mathrm{MgCO}_{3} \%$ & $\mathrm{Sr}(\mathrm{ppm})$ & Mn (ppm) & $\mathrm{Fe}$ (ppm) & $\delta^{13} \mathrm{C} \%$ VPDB & $\delta^{18} \mathrm{O} \% \mathrm{VPDB}$ & \multicolumn{2}{|c|}{${ }^{87} \mathrm{Sr} r^{86} \mathrm{Sr} \pm 2 \sigma$} \\
\hline BH67 & $\mathrm{C} 1$ & 2.0 & 97.1 & 2.9 & 479 & 148 & 1002 & -1.8 & -7.1 & & \\
\hline BH66 & $\mathrm{C} 1$ & 4.0 & 99.4 & 0.6 & 250 & 65 & 407 & -2.5 & -7.3 & & \\
\hline BH64 & $\mathrm{C} 1$ & 8.0 & & & & & & -2.0 & -7.0 & & \\
\hline BH62 & $\mathrm{C} 1$ & 11.0 & 98.8 & 1.2 & 384 & 87 & 648 & -2.8 & -7.2 & & \\
\hline BH56 & $\mathrm{C} 1$ & 22.0 & & & & & & -3.0 & -6.0 & & \\
\hline BH55 & $\mathrm{C} 1$ & 24.0 & & & & & & -4.2 & -7.1 & & \\
\hline BH51 & $\mathrm{C} 1$ & 31.5 & & & & & & -3.0 & -7.7 & & \\
\hline BH49 & $\mathrm{C} 1$ & 35.0 & & & & & & -3.2 & -7.0 & & \\
\hline BH47 & $\mathrm{C} 1$ & 38.0 & & & & & & -2.8 & -8.5 & & \\
\hline $\mathrm{BH} 43$ & $\mathrm{C} 1$ & 46.0 & 99.0 & 1.0 & 419 & 38 & 186 & -2.9 & -7.3 & & \\
\hline BH37 & $\mathrm{C} 1$ & 56.0 & 99.2 & 0.8 & 380 & 62 & 100 & -3.0 & -7.6 & & \\
\hline BH28 & $\mathrm{C} 1$ & 74.0 & & & & & & -3.0 & -7.6 & & \\
\hline BH22 & $\mathrm{C} 1$ & 86.5 & 98.7 & 1.3 & 357 & 47 & 269 & -2.8 & -7.6 & & \\
\hline BH16 & $\mathrm{C} 1$ & 98.0 & 98.8 & 1.2 & 360 & 57 & 388 & -2.5 & -7.5 & & \\
\hline BH10 & $\mathrm{C} 1$ & 111.5 & & & & & & -2.3 & -7.8 & & \\
\hline BHOG & $\mathrm{C} 1$ & 120.0 & & & & & & -2.2 & -8.0 & & \\
\hline BHO4 & $\mathrm{C} 1$ & 124.0 & & & & & & -1.9 & -7.0 & & \\
\hline BH02 & $\mathrm{C} 1$ & 128.0 & 99.2 & 0.8 & 242 & 62 & 284 & -2.6 & -8.1 & & \\
\hline BH-A23 & $\mathrm{C} 1$ & 132.0 & & & & & & -3.6 & -7.7 & & \\
\hline BH-A14 & $\mathrm{C} 1$ & 152.0 & & & & & & -1.8 & -6.8 & & \\
\hline BH-A02 & $\mathrm{C} 1$ & 175.0 & 99.1 & 0.9 & 304 & 78 & 228 & -2.3 & -8.1 & & \\
\hline BH-A01 & $\mathrm{C} 1$ & 177.0 & 99.2 & 0.8 & 268 & 57 & 280 & -2.0 & -8.5 & & \\
\hline BH31-Cf & $\mathrm{C} 1$ & 68.0 & & & & & & -4.4 & -8.7 & & \\
\hline BH67 & $\mathrm{C} 2$ & 2.0 & & & & & & -2.1 & -7.2 & & \\
\hline BH64 & $\mathrm{C} 2$ & 8.0 & & & & & & -1.8 & -7.5 & & \\
\hline BH62 & C2 & 11.0 & & & & & & -2.5 & -7.1 & & \\
\hline BH55 & $\mathrm{C} 2$ & 24.0 & & & & & & -3.6 & -7.8 & & \\
\hline BHOG & $\mathrm{C} 2$ & 120.0 & 99.2 & 0.8 & 392 & 165 & 264 & -2.3 & -7.7 & & \\
\hline BH-A04-1 & $\mathrm{C} 2$ & 171.0 & & & & & & -2.2 & -8.2 & & \\
\hline BH-A01 & $\mathrm{C} 2$ & 177.0 & & & & & & -2.1 & -8.6 & & \\
\hline BH62 & C3 & 11.0 & 99.1 & 0.9 & 356 & 77 & 119 & -2.6 & -7.1 & 0.708954 & 0.000007 \\
\hline BH53 & C3 & 28.0 & & & & & & -3.4 & -8.5 & & \\
\hline BH51vc & C3 & 24.0 & 95.4 & 4.6 & 66 & 182 & 1288 & -5.6 & -10.3 & 0.709221 & 0.000008 \\
\hline BH34vc & C3 & 62.0 & 99.5 & 0.5 & 132 & 21 & 1133 & -3.7 & -10.7 & 0.709449 & 0.000007 \\
\hline BH34vc-2 & C3 & 62.0 & & & & & & -3.2 & -13.0 & 0.708912 & 0.000006 \\
\hline BH3O & $\mathrm{C} 3$ & 70.0 & & & & & & -3.5 & -9.2 & & \\
\hline BH 29 & C3 & 72.0 & 99.8 & 0.2 & 178 & 1247 & 761 & -3.5 & -8.9 & & \\
\hline BH17 & C3 & 96.0 & 99.5 & 0.5 & 70 & 50 & 147 & -2.8 & -11.5 & & \\
\hline BH15a & C3 & 100.0 & 98.3 & 1.7 & 364 & 145 & 770 & -3.0 & -9.7 & 0.709106 & 0.000007 \\
\hline BH-A11 & $\mathrm{C} 3$ & 109.5 & 98.8 & 1.2 & 107 & 75 & 91 & -3.2 & -7.0 & 0.708849 & 0.000007 \\
\hline BH60 & D1 & 15.0 & & & & & & -2.4 & -6.3 & & \\
\hline BH58 & D1 & 18.0 & 77.5 & 22.5 & 193 & 715 & 9124 & -2.0 & -6.6 & & \\
\hline BH53 & D1 & 28.0 & & & & & & -3.2 & -5.9 & & \\
\hline BH50 & D1 & 34.0 & & & & & & -3.2 & -5.2 & & \\
\hline BH45 & D1 & 41.0 & 72.4 & 27.6 & 110 & 306 & 2469 & -2.7 & -4.0 & & \\
\hline BH41 & D1 & 50.0 & & & & & & -3.3 & -6.7 & & \\
\hline $\mathrm{BH} 40$ & D1 & 51.0 & 79.3 & 20.7 & 98 & 391 & 1705 & -2.5 & -7.7 & & \\
\hline $\mathrm{BH} 38 \mathrm{~b}$ & D1 & 54.0 & 71.5 & 28.5 & 128 & 182 & 1247 & -2.4 & -6.5 & 0.709116 & 0.000006 \\
\hline BH36 & D1 & 58.0 & & & & & & -2.4 & -6.8 & & \\
\hline BH35 & D1 & 60.0 & & & & & & -2.5 & -6.9 & & \\
\hline BH34 & D1 & 62.0 & & & & & & -2.4 & -7.3 & & \\
\hline $\mathrm{BH} 33$ & D1 & 63.5 & & & & & & -2.1 & -5.6 & & \\
\hline BH32 & D1 & 66.0 & 76.4 & 23.6 & 198 & 244 & 1398 & -1.9 & -6.1 & 0.709208 & 0.000007 \\
\hline BH3O & D1 & 70.0 & 75.0 & 25.0 & 187 & 270 & 1479 & -2.3 & -6.1 & & \\
\hline BH26 & D1 & 78.0 & & & & & & -1.8 & -5.8 & & \\
\hline BH24 & D1 & 82.0 & 74.3 & 25.7 & 166 & 251 & 3425 & -2.4 & -6.1 & 0.709668 & 0.000007 \\
\hline $\mathrm{BH} 2 \mathrm{O}$ & D1 & 90.5 & 74.4 & 25.6 & 244 & 124 & 2264 & -19 & -5.6 & & \\
\hline BH18 & D1 & 94.0 & 69.5 & 30.5 & 126 & 141 & 1986 & -2.0 & -5.4 & & \\
\hline BH14 & D1 & 102.0 & 72.6 & 27.4 & 209 & 240 & 2751 & -2.1 & -5.6 & & \\
\hline BH12 & D1 & 107.5 & & & & & & -2.3 & -7.1 & & \\
\hline BH08 & D1 & 115.0 & 72.2 & 27.8 & 138 & 553 & 5145 & -1.0 & -6.5 & 0.709908 & 0.000007 \\
\hline BH-A17 & D1 & 146.0 & 76.9 & 23.1 & 204 & 239 & 2533 & -1.7 & -6.6 & 0.708797 & 0.000008 \\
\hline BH-A15 & D1 & 150.5 & 72.4 & 27.6 & 175 & 304 & 2385 & -1.1 & -6.5 & & \\
\hline BH-A11 & D1 & 157.0 & & & & & & -1.5 & -6.6 & & \\
\hline BH-A09 & D1 & 161.0 & & & & & & -1.8 & -6.3 & & \\
\hline BH-A07-2 & D1 & 165.0 & 69.4 & 30.6 & 132 & 163 & 2593 & -0.9 & -7.3 & 0.709435 & 0.000007 \\
\hline
\end{tabular}


Appendix 1. (Continued.)

\begin{tabular}{|c|c|c|c|c|c|c|c|c|c|c|c|}
\hline Sample id \# & Phase & Depth (m) & $\mathrm{CaCO}_{3} \%$ & $\mathrm{MgCO}_{3} \%$ & $\mathrm{Sr}(\mathrm{ppm})$ & Mn (ppm) & $\mathrm{Fe}(\mathrm{ppm})$ & $\delta^{13} \mathrm{C} \%$ VPDB & $\delta^{18} \mathrm{O} \%$ VPDB & \multicolumn{2}{|c|}{${ }^{87} \mathrm{Sr} /{ }^{86} \mathrm{Sr} \pm 2 \sigma$} \\
\hline BH-A05 & D1 & 168.0 & 75.6 & 24.4 & 236 & 276 & 3017 & -1.7 & -5.7 & & \\
\hline $\mathrm{BH}-\mathrm{A} 03$ & D1 & 173.0 & 68.5 & 31.5 & 143 & 218 & 3290 & -1.4 & -5.7 & & \\
\hline $\mathrm{BH} 48$ & D2 & 36.0 & & & & & & -3.0 & -7.8 & & \\
\hline $\mathrm{BH} 44$ & D2 & 43.0 & 70.2 & 29.8 & 174 & 193 & 1578 & -2.7 & -6.3 & 0.709007 & 0.000006 \\
\hline $\mathrm{BH} 42$ & D2 & 48.0 & 76.7 & 23.3 & 299 & 280 & 1725 & -2.5 & -5.7 & 0.709073 & 0.000007 \\
\hline $\mathrm{BH} 40$ & D2 & 51.0 & 61.0 & 39.0 & 94 & 179 & 2277 & -2.4 & -7.9 & & \\
\hline BH38a & D2 & 124.0 & 57.9 & 42.1 & 48 & 360 & 3147 & & & & \\
\hline BH35a & D2 & 118.0 & 61.0 & 39.0 & 94 & 179 & 2277 & -2.2 & -7.9 & & \\
\hline $\mathrm{BH}-\mathrm{A} 21$ & D2 & 137.0 & 64.1 & 35.9 & 61 & 173 & 3808 & & & & \\
\hline BH-A19 & D2 & 141.0 & 68.3 & 31.7 & 187 & 111 & 1393 & -1.1 & -6.3 & & \\
\hline BH-A13 & D2 & 154.0 & 65.6 & 34.4 & 186 & 107 & 2696 & -1.1 & -6.4 & 0.709335 & 0.000007 \\
\hline BH-A11 & D2 & 157.0 & & & & & & -1.1 & -5.2 & & \\
\hline $\mathrm{BH}-\mathrm{A} 07-2$ & D2 & 165.0 & 75.7 & 24.3 & 153 & 142 & 1089 & -1.5 & -6.3 & 0.709065 & 0.000007 \\
\hline BH51vc-1 & D3 & 24.0 & 70.0 & 30.0 & 140 & 373 & 5825 & -3.5 & -7.4 & 0.708733 & 0.000007 \\
\hline $\mathrm{BH} 34 \mathrm{vc}$ & D3 & 62.0 & & & & & & & & 0.709544 & 0.000007 \\
\hline BH-A19-2 & D3 & 141.0 & 77.4 & 22.6 & 94 & 134 & 1264 & -4.3 & -9.3 & 0.708669 & 0.000007 \\
\hline BH-A17 & D3 & 146.0 & & & & & & -1.9 & -8.2 & 0.709200 & 0.000007 \\
\hline
\end{tabular}

D1=dolomicrite-earliest dolomite phase, $\mathrm{D} 2=$ middle dolomite phase, $\mathrm{D} 3$ = latest saddle dolomite phase

$\mathrm{C} 1=$ micrite, $\mathrm{C} 2=$ early equant meteoric cement, and C3 = fracture-filling calcite cement 